\title{
Bedrock Geology of the
}

\section{Conconully Quadrangle,}

\section{Okanogan County, Washington}

G E O L O G I C A L S UR V E Y B ULLETIN 1402

Prepared in cooperation with

the Washington Department of

Natural Resources,

Geology and Earth Resources Division

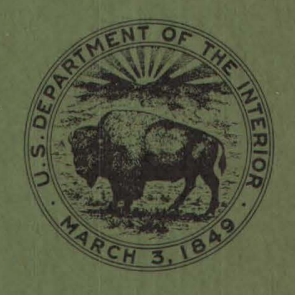




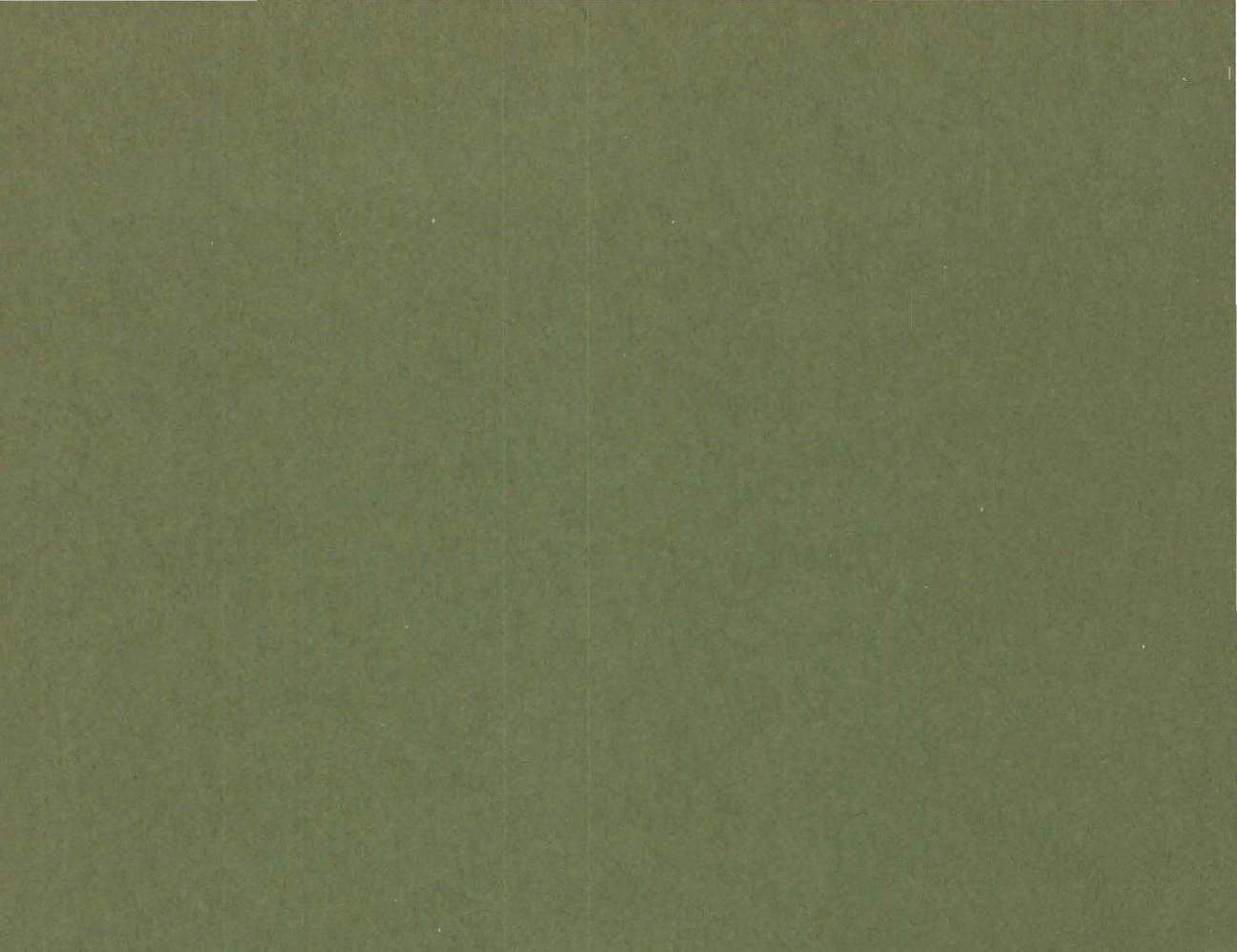




\section{Bedrock Geology of the}

\section{Conconully Quadrangle,}

\section{Okanogan County, Washington}

By C. DEAN RINEHART and KENNETH F. FOX, JR.

G E O L O G I C A L S U R V E Y B U L L E T I N 1402

Prepared in cooperation with

the Washington Department of

Natural Resources,

Geology and Earth Resources Division

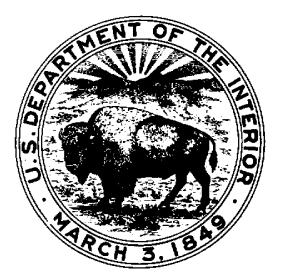

UNITED STATES PRINTING OFFICE, WASHINGTON: 1976 


\section{UNITED STATES DEPARTMENT OF THE INTERIOR}

THOMAS S. KLEPPE, Secretary

\section{GEOLOGICAL SURVEY}

V. E. McKelvey, Director

Library of Congress Cataloging in Publication Data

Rinehart, Charles Dean, 1922-

Bedrock geology of the Conconully quadrangle, Okanogan County, Washington.

(Geological Survey Bulletin 1402)

Bibliography: p. 57-58.

Supt. of Docs. no.: I 19.3:1402

1. Geology-Washington (State)-Okanogan Co. I. Fox, Kenneth F., joint author. II.

Washington (State). Geology and Earth Resources Division. III. Title. IV. Series:

United States Geological Survey Bulletin 1402.

QE75.B9 no. 1402 [QE176.035] 557.3'08s [557.97'28] 75-619052

For sale by the Superintendent of Documents, U. S. Government Printing Office Washington, D. C. 20402

Stock Number 024-001-02845-0 


\section{CONTENTS}

Abstract

Introduction

Metamorphic rocks _.... 3

Anarchist Group

Kobau(?) Formation -

Mafic intrusive rocks _____._. 8

Cave Mountain Formation

Dark-gray metalimestone member _..._. 10

Metasiltstone member -...- 10

Metadolomite and metalimestone member _._._._._._._._._._._._. 11

Slate and metalimestone member

Basaltic metavolcanic member - 15

Metamorphic complex of Conconully _-_._- 16

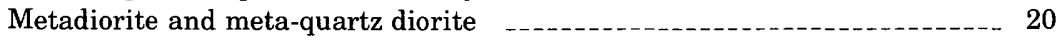

Metamorphosed hypabyssal intrusive rocks in dikes and small masses_._._- 21

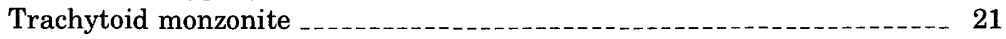

Rocks of felsic and intermediate composition

Granitoid gneiss _...

Plutonic rocks _-_-__. 23

Loomis pluton

Blue Goat pluton -

Dunn Mountain pluton

Aeneas Creek pluton

Granitic rocks in dikes and small masses _._._._._. 35

Evans Lake pluton

Quartz monzonite west of Salmon Creek

Rocks of the Okanogan gneiss dome

Sandstone and conglomerate

Volcanic rocks

Dacite of Carter Mountain _....... 39

Crystal-lithic and crystal tuff

Quartz-poor flow

Quartz-bearing flow _._. 40

Intrusive rocks -

Volcanic rocks, undivided _... 41

Andesite of Twin Peaks _..._._. 41

Petrochemistry _...... 41

Surficial deposits _ _......... 44

Geologic structure _. 46

Deformational history _... 51

Mineral deposits _._-_-_-_-__- 53

References cited 


\section{ILLUSTRATIONS}

Plate 1. Geologic map and sections of the Conconully quadrangle ---- In pocket

Figure 1. Index map of Washington, showing location of the Conconully quadrangle

2-6. Photographs showing:

2. View eastward overlooking the town of Conconully

3. Foliated sharpstone conglomerate in the Anarchist Group -- 5

4. Crossbedded and channeled sandstone interbedded in metadolomite and metalimestone member of the Cave Mountain Formation

5. Contorted bedding in marble lenticle on northeast side of Funk Mountain

6. Granitoid gneiss from Tarheel Hill, showing three ages of dikes

7. Modal plots of plutonic rocks in Conconully quadrangle

8. Isopleth maps of Blue Goat pluton showing color index and specific gravity

9. Correlation of color index and specific gravity of rocks from the Blue Goat pluton

10. Silica versus refractive index curve for Cenozoic volcanic rocks in the Conconully quadrangle

11. Silica variation diagram from Cenozoic volcanic rocks

12. Silica variation diagram showing alkali-lime index (Peacock, 1931) of the Cenozoic volcanic suite in the Conconully quadrangle

13. Photograph of minor folds typical of metasiltstone in the metamorphic complex of Conconully

\section{TABLES}

TABLE 1. Modes and specific gravity of plutonic rocks

2. Chemical and spectrographic analyses and CIPW norms and modes of granitic rocks

3. Mineral ages of some granitic rocks from the Conconully quadrangle 33

4. Chemical and spectrographic analyses and CIPW norms of volcanic rocks; nomenclature after Rittman (1952) 


\title{
BEDROCK GEOLOGY OF THE CONCONULLY QUADRANGLE, OKANOGAN COUNTY, WASHINGTON
}

\author{
By C. Dean Rinehart and Kenneth F. Fox, Jr.
}

\section{ABSTRACT}

The Conconully quadrangle, in north-central Washington, straddles the boundary between the composite Cascade Range and the adjoining Okanogan Highlands. Threefourths of the quadrangle is occupied by mainly greenschist-grade metamorphic rocks of Permian and Triassic age, with the remaining area divided about equally between granitic rocks of Triassic to Cretaceous ages and volcanic rocks of Eocene age. The oldest rocks are those of the Anarchist Group, of probable Late Permian age. The Anarchist consists mainly of fine-grained laminated to thick-bedded pelitic and siliceous metasiltstone and minor but ubiquitous sharpstone metaconglomerate and has a minimum aggregate thickness of 1,500 to $3,000 \mathrm{~m}(5,000$ to $10,000 \mathrm{ft})$. These rocks are overlain by rocks tentatively correlated with the Kobau Formation of Permian or Triassic age. The contact between the Anarchist and the Kobau(?) and between the Anarchist and rocks of Triassic age is locally marked by a distinctive zone of magnesitic dolomite and associated chrome mica. The Triassic rocks include the Cave Mountain Formation and the overlying metamorphic complex of Conconully. The Cave Mountain Formation is a distinctive sequence of five dominantly carbonate units totaling between 1,200 and $1,500 \mathrm{~m}(4,000$ and 5,000 ft) thick, one unit of which yielded diagnostic fossils. The metamorphic complex of Conconully is composed mostly of rock types similar to the fine-grained epiclastic rocks of the Anarchist Group except that the complex includes abundant interlayered greenschist and greenstone; sharpstone conglomerate is rare. The complex is probably a few thousand metres thick, although the unit is virtually devoid of stratigraphic marker horizons.

The granitic terrane is characterized by small, typically granodioritic plutons that were intruded into previously metamorphosed rocks whose gross structure markedly affected pluton shapes. One pluton shows evidence of concentric zoning, and nearly all show local thermal metamorphism of wallrocks, resulting in coarsening of grain size and sparse development of kyanite, sillimanite, garnet, and chloritoid.

Volcanic rocks, of Eocene age, form a discrete sequence 1,200 to $1,500 \mathrm{~m}(4,000$ to $5,000 \mathrm{ft})$ thick that occupies $41 \mathrm{~km}^{2}\left(16 \mathrm{mi}^{2}\right)$ in the eastern part of the quadrangle and comprises andesitic to quartz latitic flows and crystal tuffs. Small discontinuous patches of similar volcanic rocks occupy an additional area of $8 \mathrm{~km}^{2}\left(3 \mathrm{mi}^{2}\right)$ in the northern part of the quadrangle. Surficial deposits, in addition to alluvial deposits, include glacial drift that forms a blanket of silt, sand, and gravel of varied thickness over much of the area.

The geologic structure is dominated by a pair of large northwest-trending folds, overturned to the southwest, in the northern part of the quadrangle and a broad, open, east-northeast-trending anticline in the southern part. Myriads of minor folds with complex geometric interrelations are superimposed on the major structures, indicating 
a complex deformational history in the region. A westward-projecting salient of the Okanogan gneiss dome extends from the east into the southeastern part of the quadrangle. Overturned folds and thrust faults in the adjacent metamorphic terrane are attributed to forcible emplacement of the dome. Elsewhere mapped faults dip steeply, with displacements generally measured in tens rather than hundreds of metres.

Lode deposits, chiefly of silver and lead but including minor copper and gold, are clustered mainly in the southwestern part of the quadrangle and are part of what was probably the most active mining district in the region prior to 1900 . Mining activity has been sporadic since the early part of this century.

\section{INTRODUCTION}

The Conconully quadrangle is in the central part of Okanogan County in the north-central part of the State of Washington (fig. 1). On the west, the quadrangle includes part of the rugged margin of the Okanogan Range-easternmost range of the composite Cascade Range-and on the east, part of the rolling uplands known as the Okanogan Highlands. Sinlahekin Valley and its southward extension to Fish Lake cuts through the west-central part of the quadrangle and forms a natural boundary between the Okanogan Range and the Okanogan Highlands. Glaciation has sculptured the valleys, especially the north-trending ones, and has rounded the intervening uplands and blanketed the bedrock with drift (fig. 2). Three-fourths of

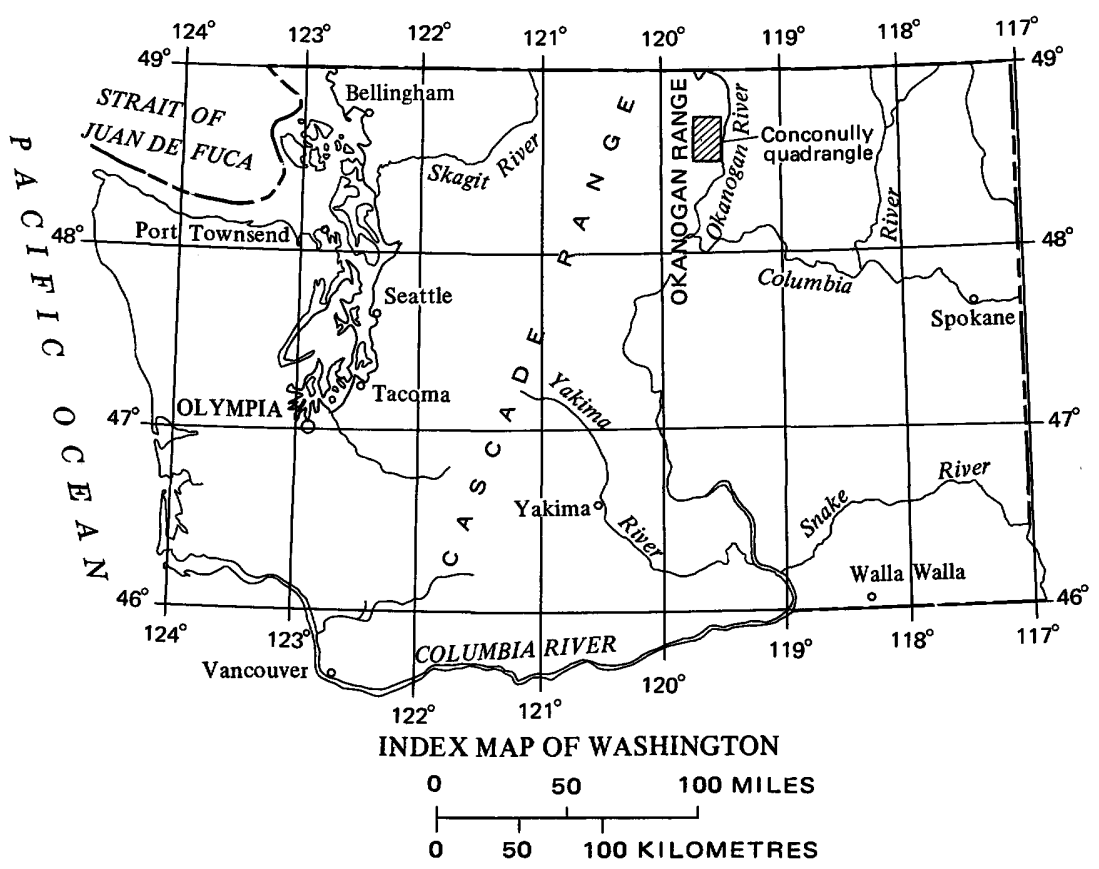

FIGURE 1.-Index map of Washington, showing location of the Conconully quadrangle. 


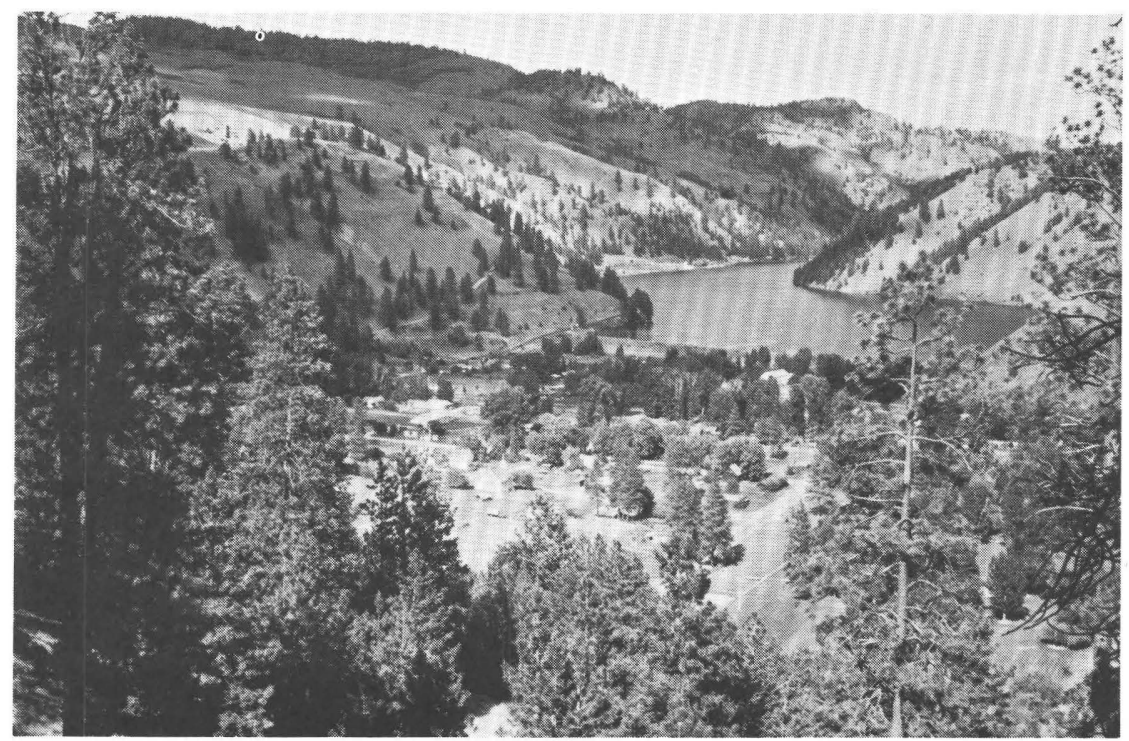

FIGURE 2.-View eastward overlooking the town of Conconully. Conconully Lake lies in the trough between the slopes of Funk Mountain, on the left, and Tarheel Hill, on the right. Low summit on the far skyline is Schallow Mountain. Topography and tree density are typical of the area.

the quadrangle is underlain by metamorphic rocks, and the other fourth by plutonic and volcanic rocks.

In addition to the published works cited in the text that follows, unpublished theses relating to the Conconully quadrangle by the following authors were consulted during the course of this study and are listed in the references: R. W. Adams, R. Goldsmith, L. T. Grose, M. J. Hibbard, F. J. Menzer, Jr., and H. A. Pelton. An unpublished geologic map of part of the carbonate terrane between Riverside and Conconully, made during the late 1930's by R. J. Roberts and S. W. Hobbs, was kindly furnished by R. J. Roberts. W. H. Nelson generously loaned us his field notes and annotated aerial photographs of part of the same area, acquired in 1950 as a result of participation in a University of Washington field mapping course under the direction of Peter Misch. The authors were ably assisted in the field by J. Casey Moore. The manuscript benefitted immeasurably from painstaking technical reviews by R. C. Greene and N. K. Huber, and we are most grateful for their conscientious efforts.

\section{METAMORPHIC ROCKS}

\section{ANARCHIST GROUP}

The oldest rocks in the Conconully quadrangle belong to the Up- 
per(?) Permian Anarchist Group, redefined by Rinehart and Fox (1972, p. 8) from Daly's (1912, pt. 1, p. 389) original Anarchist Series. The Anarchist Group consists of variably metamorphosed epiclastic rocks, including siltstone, argillite, sandstone, graywacke, arkose, and chert-pebble conglomerate, with subordinate interlayers of limestone, lava flows, and pyroclastic rocks. In the Loomis quadrangle, adjacent to the Conconully quadrangle on the north, the Anarchist comprises two formations, the Spectacle Formation and the overlying Bullfrog Mountain Formation, totaling about 6,000 m (20,000 ft) in exposed thickness.

There, the presence of abundant metalimestone in the Spectacle, and the near absence of metalimestone in the Bullfrog Mountain Formation, was the basis for distinguishing between the two formations. This distinction, however, has not been made in the Conconully quadrangle, where the rarity of metalimestone in the Anarchist suggests that most of these rocks are correlative with the Bullfrog Mountain Formation except perhaps at two localities: (1) in the vicinity of the conspicuous west-northwest-trending layers of metalimestone near the contact of the Anarchist and the Conconully complex in the northeastern part of the quadrangle, and (2) the small knobs of limestone in Horse Springs Coulee in the extreme northeastern part of the quadrangle. The rocks at these two localities probably correlate with the Spectacle Formation, but because the structure is complex and the limestone is not continuous with mapped Spectacle in the Loomis quadrangle, the subdivision is not made here. The base of the Anarchist is not exposed in the Conconully quadrangle, but the exposed thickness is probably between 1,500 and $3,000 \mathrm{~m}(5,000$ to $10,000 \mathrm{ft}$ ).

In the northern part of the Conconully quadrangle, the Anarchist Group consists typically of weakly metamorphosed medium- to dark-gray laminated to thick-bedded, siliceous and argillaceous siltstone, sandstone, and less abundant siliceous sharpstone conglomerate (fig. 3). In the conglomerate, the largest fragments average about $2.5 \mathrm{~cm}$ (1 in.) in length but may be as much as $30 \mathrm{~cm}(1 \mathrm{ft})$ long. Chert constitutes the bulk of the clasts, and argillaceous, calcareous, and volcanic clasts are present in lesser amounts.

Foliation is typically inconspicuous but locally pronounced in zones a few metres to a few hundred metres wide. The general metamorphic grade is greenschist facies, with local variation to amphibolite facies. Development of knotted hornfels was noted in argillaceous rocks south of Lemanasky Mountain, and chloritoid is present near the south end of the Aeneas Creek pluton.

Deformation and recrystallization are most extensive in the schistose and gneissic terrane north and west of Sinlahekin Creek in the 


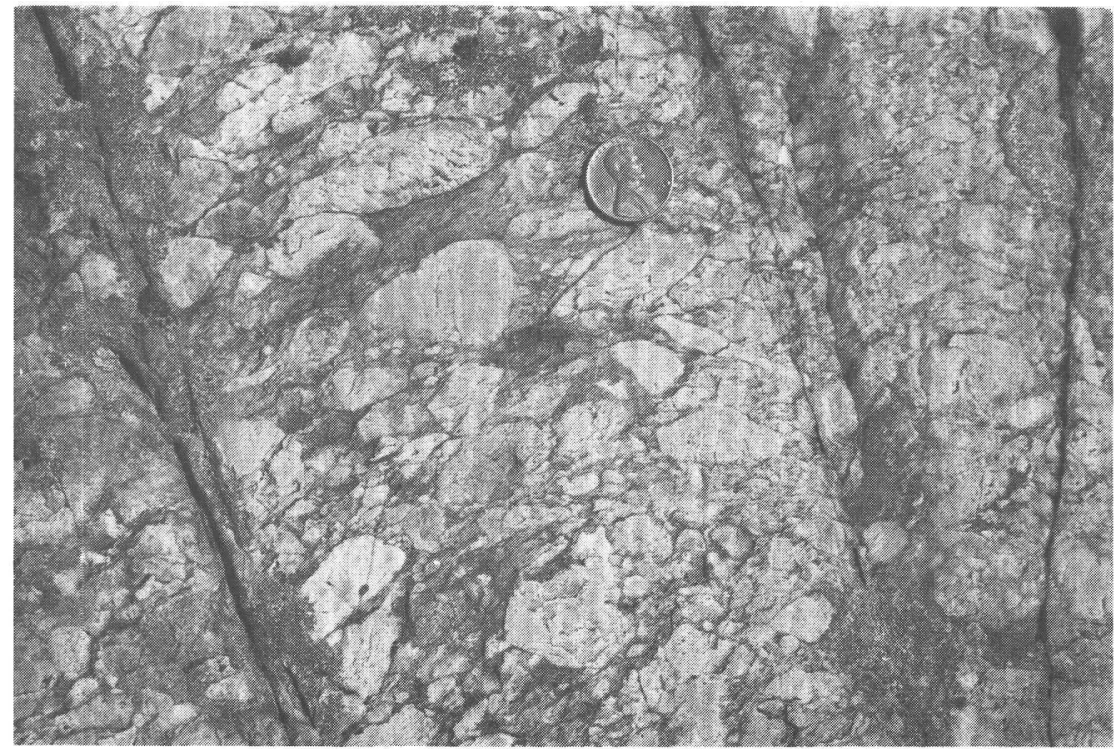

FIGURE 3.-Foliated sharpstone conglomerate in the Anarchist Group showing stretched and flattened clasts; specimen from window in the Cave Mountain Formation.

northwest corner of the quadrangle where andalusite, garnet, and rare anthophyllite are found and where deformed clasts in metaconglomerates have approximate length-to-width ratios of 15 . In this same area, the Anarchist is extensively cut by metamorphosed blastoporphyritic dacitic dikes and sills that are grossly similar to a swarm of metamorphosed dikes and sills exposed in a small area about $11 \mathrm{~km}(7 \mathrm{mi})$ to the south, midway between Fish Lake and Schallow Mountain. Because the dynamic metamorphism of the hypabyssal intrusive rocks was not uniform, their textures range from almost structureless, little deformed dacite porphyry to augen and flaser gneisses in which the length-to-width ratio of deformed andesine phenocrysts is 10 or more. A typical specimen consists of phenocrysts of andesine in a matrix of quartz, biotite, and hornblende and has a color index of about 15 .

On Cayuse Mountain in the extreme northeastern corner of the quadrangle, the general lithology of the Anarchist is similar to that elsewhere except that the characteristic coarse chert-pebble metaconglomerate is absent, although metamorphosed finer grained clastic rocks including graywacke, arkose, and granule conglomerate are abundant. Almost all these rocks, except the most siliceous, are phyllitic, and some have been reduced to cataclasites through intense shearing in the plane of foliation. A distinctive feature of the catacla- 
sites is the occurrence of discrete, equant to lenticular relict quartz grains, commonly dispersed sparingly through even the finest grained phyllite. The quartz grains commonly show evidence of mortar structure that has been modified by partial recrystallization to mosaic texture, yet their size is typically several orders of magnitude larger than the grain size of the matrix.

In exposures west of Wagonroad Coulee (southeastern part of quadrangle) as well as in the outcrop (in sec. 27, T. $25 \mathrm{~N}$., R. 25E) south of Scotch Creek Grange Hall, the most abundant rock type in the Anarchist Group is medium-gray quartzite metaconglomerate with a perceptible to marked greenish cast due to the presence of fuchsite (chromium-bearing mica). Sparse beds of locally phyllitic metasiltstone, fine-grained metasandstone (orthoquartzite), and metagraywacke are interbedded with the metaconglomerate.

Scattered throughout the Anarchist are discontinuous, commonly highly contorted beds of metalimestone. These rocks are laminated to thick bedded and range in color from dark to light gray. They are typically fine grained and almost free of impurities except for a little chert locally. Southeast of Lemanasky Lake in the north-central part of the quadrangle, however, the mapped beds of metalimestone grade laterally into the adjacent coarse and fine clastic rocks. Elsewhere, contacts with adjacent metaclastic rocks are rarely visible but are probably abrupt, for adjacent rocks are typically not calcareous and have no limestone interbeds. Metalimestone in the southern half of the mapped small lens west of Lemanasky Lake is uniquely rich in medium- to coarse-grained bioclastic debris, much of which is crinoidal. No fossil debris was found in the largest metalimestone unit, but at three localities several tens of metres north of its northern contact, abundant crinoidal columnals, as large as $23 \mathrm{~mm}$ (0.9 in.) in diameter, were found in calcareous metagraywacke (see symbols on pl. 1) that is virtually indistinguishable from fossil-bearing beds of the Spectacle Formation in the Loomis quadrangle (Rinehart and Fox, 1972, p. 9).

The Anarchist also contains scattered, thin layers of greenstone comprising medium- to fine-grained metamorphosed tuff, volcanic wacke, lava flows, and hypabyssal intrusive rocks. These rocks are dark gray to dark greenish gray and, judging from their fairly high specific gravities, are basaltic or andesitic in composition. The greenstone is typically less well foliated than adjacent metamorphosed epiclastic rocks. The two mapped greenstone bodies near Lemanasky Lake are pyroclastic, at least in part, and grade locally into epiclastic rocks. 
KOBAU(?) FORMATION

At its reference locality to the north in the Loomis quadrangle, the Kobau Formation consists of a thick sequence of unfossiliferous grayish-green phyllite, greenstone, and massive metachert. The Kobau unconformably overlies the Permian Anarchist Group (Rinehart and Fox, 1972) and is cut by the Loomis pluton of Late Triassic age; its age is therefore considered to be Permian or Triassic.

Rocks mapped as the Kobau(?) Formation at Cayuse Mountain in the northeastern corner of the Conconully quadrangle lithologically resemble the Kobau at its reference locality except that metachert is absent at Cayuse Mountain; at both localities the formation overlies the Anarchist Group. It seems advisable, however, to query the formational name in this quadrangle, partly because of the absence of metachert, which is a rock type distinctive of the type Kobau, and partly because of the isolation of Cayuse Mountain from the reference locality.

At its exposure on Cayuse Mountain, the Kobau(?) Formation occupies about $5 \mathrm{~km}^{2}\left(2 \mathrm{mi}^{2}\right)$ and is composed chiefly of greenish-gray, calcareous, phyllitic metasiltstone interbedded and intergrading with phyllitic metalimestone; these rocks are interlayered with fairly continuous beds (sills?) of greenstone. One of these, a probable metapyroclastic rock, is sufficiently thick and extensive to show on the geologic map (pl. 1). Metadolomite, quartzitic metasiltstone, and metasandstone are also locally present within the formation. The contact of the Kobau(?) with the Anarchist was arbitrarily placed at the lowest (easternmost) greenstone layer. However, the quartzitic metasiltstones that are thereby included within the lower hundred metres or so of the Kobau(?) on Cayuse Mountain closely resemble the rocks of the subjacent Anarchist, producing at least an appearance of gradation between the two units. Possibly some or all of the rocks included in the basal Kobau(?) are, in fact, a greenstonebearing part of the Anarchist. The problem is compounded by probable infolding of the two units, suggested by the presence of cataclastic textures and minor structures including lineations and minor folds. Because of these complexities, it is impossible to make a reliable estimate of the thickness of the Kobau(?). Assuming, however, no major repetition of strata by folding or faulting, the maximum thickness is approximately $1,100 \mathrm{~m}(3,500 \mathrm{ft})$.

A thick layer of homogeneous, nearly structureless, light-gray metadolomite bordered on the east by a discontinuous layer of metalimestone, both layers containing sparse chert nodules, forms a conspicuous outcrop $1 \frac{1 / 2}{\mathrm{~km}}$ (nearly a mile) long in the central part of 
the Kobau(?). A few patches of orange-brown-weathering magnesitic metadolomite are scattered randomly along the metadolomite bed (locality P in Fox and Rinehart, 1968, table 1 and pl. 1); distribution of the magnesite appears to be controlled by fractures, at least locally. Modal analyses on samples stained for magnesite show concentrations as high as 61 percent (Fox and Rinehart, 1968, table 3, p. B9). Tiny patches of bright-green mica-probably fuchsite-are evident in many magnesitic specimens. Magnesitic rocks from this locality are generally similar to others in the belt of magnesitic rocks extending more than $30 \mathrm{~km}(20 \mathrm{mi})$ to the north and east, including their stratigraphic proximity to the Paleozoic-Mesozoic boundary.

Amphibolite and greenstone occurring as fine- to medium-grained greenish, weakly foliated or structureless, actinolite- and chloriterich rocks typically form concordant layers a few metres to a few tens of metres (10-100 ft) thick but also occur as discontinuous, irregularly shaped masses; the amphibolite and greenstone commonly intergrade. Greenstone may be more abundant than presently suspected because thin-section examination of two specimens identified in the field as probable metasiltstone showed the rocks to be metavolcanic. Many concordant layers probably originated as lava flows and tuffs, but some of the irregularly shaped masses are probably small hypabyssal intrusive bodies.

The isolated outcrop of the formation in SW1/4 sec. 2, T.37 N., R.26 E. consists mainly of discontinuously bedded, weakly metamorphosed pyroclastic rock. Rock types range from microgranular tuff to tuff breccia with flattened lithic fragments as long as $5 \mathrm{~cm}$ (2 in.). Finegrained metatuffs locally contain oval albite grains, resembling oolites, in zones parallel to bedding. Unique to this outcrop area are numerous alaskite sills and a few dikes, typically a few centimetres thick but as much as $1.5 \mathrm{~m}(5 \mathrm{ft})$ thick at one locality. Near the eastern margin of the outcrop area, the greenstone grades into calcareous phyllite similar to rocks of the main outcrop area to the east. The entire Kobau(?) has been metamorphosed to chlorite grade.

\section{MAFIC INTRUSIVE ROCKS}

The mafic intrusive rocks include numerous small irregular elongate bodies of greenstone, metadiabase, metagabbro, metadiorite, amphibolite, and less abundant felsic variants, that are intruded into the Anarchist Group, Kobau(?) Formation, and the metamorphic complex of Conconully. Most abundant is metadiabase that in many places grades into aphanitic greenstone or locally into coarser grained metagranitoid rocks. Most of the bodies are at least somewhat elongate parallel to the local structure of the enclosing rocks, though many show crosscutting relations in detail. Some are entirely 
discordant-for example, some of the bodies that cut across the carbonate unit southwest of Aeneas Creek. The rocks are typically greenish gray to dark greenish gray and massive but locally schistose, and have textures that are variously diabasic, hypidiomorphicgranular, and porphyritic. Patchy, erratic variation in grain size from fine to medium is a characteristic feature in nearly all bodies. Essential minerals typically are oligoclase or andesine, pale-green hornblende (actinolite?), biotite, epidote and (or) clinozoisite, and chlorite. Calcite is almost invariably present in amounts ranging from a trace to several percent. Quartz is rarely visible in hand specimen but in thin section is locally present in small amounts.

The mafic intrusive rocks are markedly similar in composition and degree of metamorphism to unmapped greenstone layers within both the Anarchist and Kobau(?). Hence, we view the intrusive rocks as hypabyssal intrusive equivalents of volcanic extrusive rocks that were characteristic of the depositional regime from Permian through Late Triassic time.

\section{CAVE MOUNTAIN FORMATION}

The Cave Mountain Formation, named for exposures on a low mountain in the south-central part of the quadrangle, about $3 \mathrm{~km}(2$ $\mathrm{mi}$ ) north of the southern quadrangle boundary, forms a distinctive marine stratigraphic sequence about $1,300 \mathrm{~m}(4,300 \mathrm{ft})$ thick. It occupies an area of about $80 \mathrm{~km}^{2}\left(30 \mathrm{mi}^{2}\right)$ in the southern part of the quadrangle and is at least partly a chronological equivalent of the Kobau Formation. The Cave Mountain Formation is divided into five members designated after the dominant lithology of each, from oldest to youngest: dark-gray metalimestone, metasiltstone, metadolomite and metalimestone, slate and metalimestone, and basaltic metavolcanic members. Except for the metasiltstone, the members are rich in carbonate and as a group contrast lithologically with other metamorphic units. The individual members also are mutually distinctive and readily mappable. The type locality of the Cave Mountain Formation is designated as the exposures in the dissected southern and southeastern slopes of Cave Mountain in secs. 17, 18, 19, and 20, T. 35 N., R. 26 E. The Cave Mountain Formation overlies, with probable unconformity, rocks mapped as Anarchist Group that are exposed in windows in the Cave Mountain Formation to the east near Wagonroad Coulee. The evidence that the Cave Mountain unconformably overlies the Anarchist rather than having been thrust over it has been detailed by Waters and Krauskopf (1941, p. 1365). At two localities, we have found fragments of the underlying quartzite conglomerate of the Anarchist enclosed within the lowermost layers of the overlying carbonate rocks, confirming the depositional nature of the contact. Elsewhere, the contact is either a fault, or its nature is 
equivocal because of poor exposure or absence of bedding. The Cave Mountain Formation is overlain by, and locally interbedded with, schist and metasiltstone of the metamorphic complex of Conconully.

The Cave Mountain Formation is considered to be Triassic on the basis of invertebrate fossils collected from its slate and metalimestone member, the only member in which fossils have been found.

\section{DARK-GRAY METALIMESTONE MEMBER}

Carbonaceous metalimestone, typically fine grained, dark gray, and with a sooty appearance, forms the lowermost member of the Cave Mountain Formation. The unit is generally inconspicuously bedded, but at several places near its northern and eastern boundaries it is thinly laminated. Megascopic porphyroblasts a few millimetres long are common and are mostly tremolite but include diopside and scapolite. Zones of light-colored clastic material are present locally and may be fossil debris, although no recognizable forms were found, and thorough recrystallization has generally obliterated primary textures. Sparse breccia is locally present near the upper contact of the member. Apart from a few sandy zones, other rock types within the member are rare. The upper contact is poorly exposed, but both sharp and gradational contacts with the overlying metasiltstone member were seen. The metalimestone member presumably overlies the Anarchist Group, although the subjacent beds are not exposed. The exposed thickness of the member is probably at least $300 \mathrm{~m}(1,000 \mathrm{ft})$. The metalimestone member is presumed to wedge out between its outcrop area and the windows, barely $2 \mathrm{~km}\left(1 \frac{114}{4}\right.$ mi) to the east-northeast, where the Anarchist Group is directly and unconformably overlain by the stratigraphically higher metadolomite and metalimestone member of the Cave Mountain Formation.

\section{METASILTSTONE MEMBER}

The metasiltstone member consists of vitreous medium-dark-gray metasiltstone, typically showing a slight lavender cast. East of Cave Mountain (sec. 17, 18, T. 35 N., R. 26 E.) where it is least deformed, it is approximately 60 to $100 \mathrm{~m}$ (200 to $300 \mathrm{ft}$ ) thick. The unit pinches out to the southwest and to the east as well, as it is absent in the windows exposing the Anarchist Group west of Wagonroad Coulee. The metasiltstone is thinly laminated or thinly bedded, locally crossbedded, and locally interbedded with metasandstone and metalimestone. Generally the lower contact of the metasiltstone member is concealed, but where seen it typically appears to be sharp and conformable. Locally, however, the proportion of metalimestone increases toward the base, and the member grades into the underly- 
ing dark-gray metalimestone member. Microscopically, the texture of the metasiltstone is typically granoblastic, but relict clastic texture can generally be recognized. The metasiltstone is typically a quartzbiotite-calcite-muscovite rock. Actinolite occurs in carbonate-bearing rocks east of Cave Mountain, and actinolite, diopside and scapolite west of the mountain. A pelitic interlayer near the latter locality contains andalusite as does a similar layer close to Hess Lake near the southern quadrangle boundary.

\section{METADOLOMITE AND METALIMESTONE MEMBER}

The metadolomite and metalimestone member is composed chiefly of massive metadolomite interlayered with or grading to equally massive metalimestone. In the homoclinal, south-dipping sequence forming the southern slope of Cave Mountain, the member is readily divisible into two units, a lower "white" marble unit, and an upper metadolomite and metalimestone unit. The contact between these units, where recognizable in the field, is shown as a marker horizon on the map by a discontinuous dashed line (pl. 1).

The lower of these two units is composed of massive, medium- to coarse-grained calcite marble, ranging in color from white to bluish gray. The calcite marble grades locally to fine-grained, very pale orange to yellowish-gray metadolomite. The white marble is about $170 \mathrm{~m}(600 \mathrm{ft})$ thick where intersected by cross-section $E-E^{\prime}$ (pl. 1) and thins to about $30 \mathrm{~m}$ (100 ft) thick at the western limit of its exposure. Eastward from Cave Mountain it grades to rock similar to the upper metadolomite and metalimestone unit; hence, the two units could not be distinguished in the easternmost exposures of the member. The white marble is also present at the base of the member between Cave Mountain and Dunn Mountain, where it was mapped separately from the overlying dolomite by Mills (1962, p. 233, fig. 61); the mutual contact of the two units in that area is also shown on plate 1 as a marker horizon.

The upper unit at Cave Mountain is similar to the remainder of the metadolomite and metalimestone member in the eastern part of its outcrop area-a weakly metamorphosed, pale-yellowish-brown to bluish-gray dolomite grading erratically to similarly colored limestone and dolomitic limestone. Interbeds of dark-bluish-gray, shaly limestone, 10 to $20 \mathrm{~m}$ ( 35 to $65 \mathrm{ft}$ ) thick, are present locally. Typically, the member shows only faint traces of bedding, but crude layering can usually be observed in outcrops when viewed from a distance. East of Cave Mountain the metadolomite and metalimestone member (including the $170 \mathrm{~m}$ thick lower white marble unit) is about $300 \mathrm{~m}$ $\left(1,000 \mathrm{ft}\right.$ ) thick (see section $E-E^{\prime}$, pl. 1$)$, but it thins to the southwest and thickens to the north and east. 
Interlayers of locally crossbedded quartz metasandstone (fig. 4) are fairly common in the northeasternmost exposures (S. 33, T. 36 N., R. 26 E.); fuchsite-bearing sandstone dikes were also observed there. At several localities-for example, in the south-central part of sec. 33 and also in the south-central part of sec. 10 (T. 35 N., R. 26 E) -the dolomite grades through sandy and pebbly dolomite to interbeds of conglomerate a metre or so thick. The conglomerate contains rounded to angular pebbles of varicolored chert and quartzite up to $15 \mathrm{~mm}$ long, packed in a sandy, dolomitic matrix.

The member contains sporadically distributed chert nodules 2 to 5 $\mathrm{cm}$ (1 to $2 \mathrm{in}$.) long, locally measuring as much as $15 \mathrm{~cm}$ (6 in.). The carbonate rocks in several places, particularly near the Dunn Mountain and Evans Lake plutons, contain tremolite, diopside, scapolite, brucite, garnet, serpentine, and chlorite. In the western part of the carbonate terrane, the basal contact of the member is sharp and conformable over quartzitic metasiltstone, and in the eastern part the member unconformably overlies or (less likely, in our view) is thrust over quartzitic sharpstone metaconglomerate and quartzite of the Anarchist Group.

Within a zone several metres thick near the base of the metadolomite and metalimestone member, beds and lenses of distinctive, im-

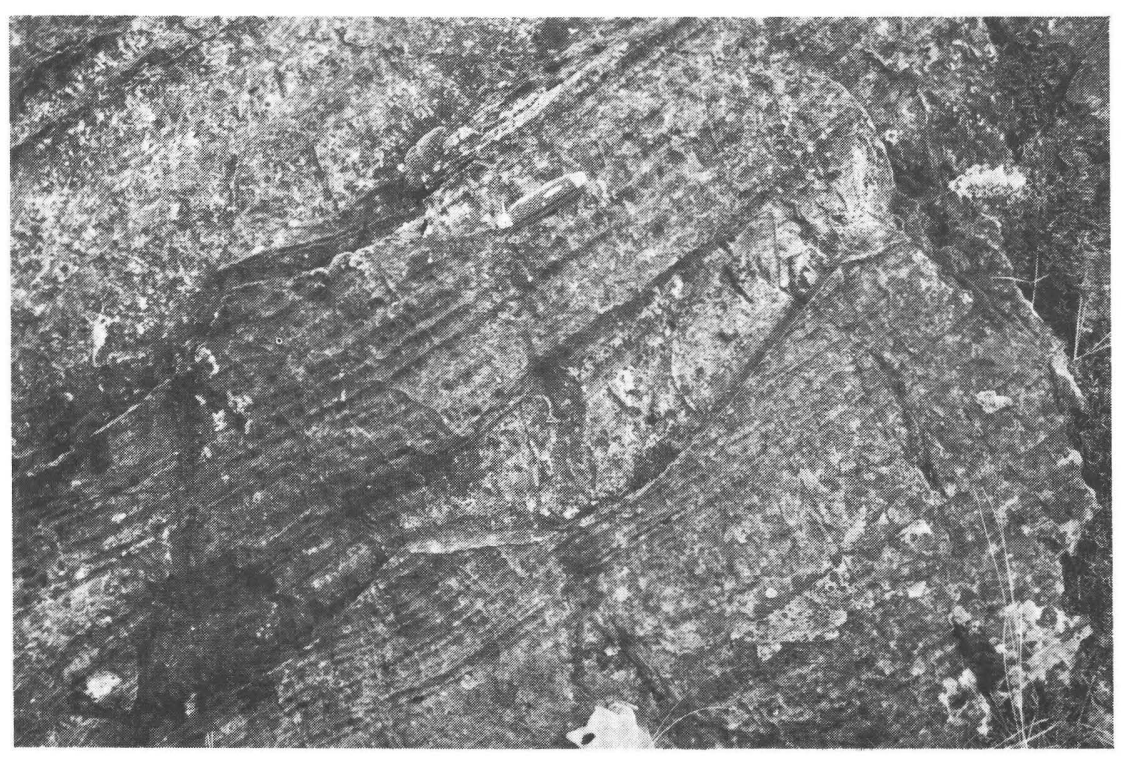

Figure 4.-Crossbedded and channeled sandstone interbedded in metadolomite and metalimestone member of the Cave Mountain Formation; from exposures in center of sec. 33 near the northeastern limit of the formation. 
pure dolomitic carbonate, less than a metre to a few metres thick, are locally interbedded with light-gray metadolomite and metasiltstone. The beds are characterized by a conspicuous grayish-orange to darkyellowish-orange rind on weathered surfaces and by disseminated tiny bright-green flakes of fuchsite. This zone is delineated separately on the geologic map (pl. 1) as magnesitic dolomite, although only a few samples show more than a trace of magnesite. One sample from the northeast quarter of sec. 4 (T. 35 N., R. 26 E.), however, is about 45 percent magnesite. The general paucity of magnesite notwithstanding, these beds, in their general appearance, composition, fuchsite content, and stratigraphic proximity to strata of the Anarchist Group, resemble the magnesitic metadolomite exposed at Cayuse Mountain in the Kobau(?) Formation that forms a belt of discontinuous outcrops extending more than $30 \mathrm{~km}(20 \mathrm{mi})$ to the north and east (Fox and Rinehart, 1968). The magnesitic zone in sec. 4 (T. $35 \mathrm{~N}, \mathrm{R} .26 \mathrm{E}$.) extends 15 to $30 \mathrm{~m}(50$ to $100 \mathrm{ft})$ downward into quartzite metaconglomerate along an anticlinal axis. The metaconglomerate, which locally has magnesitic carbonate matrix and lenses, is here included with the underlying Anarchist Group. The presence of magnesitic carbonate in the conglomerate is interpreted to result from postdepositional metasomatic redistribution of the carbonate from the overlying beds, although it is possible that this conglomerate may be a local lens of basal conglomerate of the metadolomite and metalimestone member of the Cave Mountain Formation.

Greenish-gray, mottled serpentinite forms a thick layer associated with and grading into yellowish-orange, locally magnesitic metadolomite at the base of the metadolomite and metalimestone member in sec. 4, northwest of Booher Lake; it also crops out in sec. 33 , adjacent on the north, where it is enclosed in metadolomite. In sec. 33 , the eastern contact of the largest body of serpentinite is a subhorizontal fault. Three small lozenge-shaped bodies of serpentinite lie en echelon along a line branching northeast from the larger serpentinite body in sec. 33 , each locally brecciated and occupying a subhorizontal shear zone. The chief mineral in the serpentinite is antigorite, which is mixed in varied proportions with carbonate, talc, tremolite, and chlorite. Sparse euhedral to subhedral crystals of chromite are present in both the serpentinite and nearby magnesitic conglomerate. The paragenetic relations of the carbonate and serpentine minerals are uncertain because, in some places, serpentinite replaces carbonate, and in others, carbonate replaces serpentinite. The field relations, however, suggest that the serpentinite formed through replacement of the rocks of the magnesite zone and later moved plastically along faults. 


\section{SLATE AND METALIMESTONE MEMBER}

Dark-gray slate and phyllite thinly interbedded with dark-gray, silty, commonly slaty or phyllitic metalimestone (locally grading to metadolomite) along with local beds of white marble compose the slate and metalimestone member. These lithologies are readily distinguished in the homoclinal, south-dipping sequence forming the southern slope of Cave Mountain, and in strata contiguous to the west. At Cave Mountain, the member comprises a basal zone of thinly laminated, limy metasiltstone, an intermediate zone of medium- to coarse-grained, white to light-gray marble, and an upper zone of fine-grained, dark-gray, silty metalimestone. The contact between the white marble and the overlying dark-gray metalimestone is shown as a marker horizon on the map (pl. 1).

The basal metasiltstone forms a layer 5 to $15 \mathrm{~m}$ ( 15 to $50 \mathrm{ft}$ ) thick, thinning west of Cave Mountain and interfingering to the east with dark-gray silty metalimestone and black slate. Judging from a single thin section, the primary constituents of the basal metasiltstone are quartz, calcite, potassium feldspar, and plagioclase.

The white to light-gray marble is about $60 \mathrm{~m}(200 \mathrm{ft})$ thick at Cave Mountain, thinning to the west, and apparently pinching out abruptly to the east. Thus, the slate and metalimestone member, throughout the remainder of its extent to the north and east of Cave Mountain, is composed chiefly of dark-gray slate, phyllite, and silty metalimestone. Throughout much of that area the member contains two units: (1) an upper unit composed chiefly of dark-gray slate, phyllite, and limy phyllite, grading into (2) a lower unit of dark-gray to bluish-gray silty metalimestone, which in places contains subordinate slate and phyllite similar to that in the upper unit. Where these units were distinguished in the field, they are shown separately on the map (pl. 1).

In the outlier southeast of Mud Lake (sec. 31, T. 36 N., R. 26 E.), the dark-gray slate unit contains lenses of schistose calcareous metavolcanic wacke, judged to be of pyroclastic derivation and related in origin to the overlying metavolcanic member.

The lower contact of the member is conformable and locally gradational. For example, east of Alkali Lake, basal dark bluish-gray dolomitic metalimestone belonging to this member interfingers with massive, olive-brown silty dolomite, a local phase of the underlying metadolomite and metalimestone member. The slate and metalimestone member is about $300 \mathrm{~m}(1,000 \mathrm{ft})$ thick where it is approximately homoclinal northwest of Evans Lake in the southeast part of the quadrangle.

Rocks in the southernmost exposures are locally schist and knotted hornfels, presumably reflecting thermal metamorphism by the Evans 
Lake pluton. In that area biotite is ubiquitous, and brucite, diopside, and andalusite occur sporadically. The coarsest andalusite, however, occurs in the northwesternmost exposures (south of Mud Lake in sec. 25, T. 36 N., R. 25 E.), suggesting that the small igneous masses north of the lake (sec. 24) are cupolas of a pluton that broadens abruptly with depth.

Invertebrate fossil debris was found at three localities east of Alkali Lake and from one locality $0.8 \mathrm{~km}(1 / 2 \mathrm{mi})$ south of Castor Lake. In addition, fossil bone fragments-possibly reptilian vertebraewere found at one locality near the SE corner sec. 15, T. 35 N., R. 26 E. that, although not diagnostic, are compatible with the Triassic age reported by Waters and Krauskopf (1941, p., 1366), on the basis of poorly preserved pelecypods from sec. 26 , T. 35 N., R. 26 E. A collection by Misch, presumably from the same unit, included more diagnostic forms and was considered Upper Triassic by S. W. Muller (Misch, 1966, p. 118).

\section{BASALTIC METAVOLCANIC MEMBER}

The basaltic metavolcanic member is composed chiefly of mediumdark-gray to olive-gray, schistose metabasalt and basaltic metatuff and metatuff breccia with a considerable admixture of carbonate (both dolomite and calcite) in the matrix. The member is about $300 \mathrm{~m}$ $(1,000 \mathrm{ft})$ thick. Rock textures are of three distinct types: (1) blastoporphyritic texture characterized by black, fairiy equant hornblende crystals 1 to $5 \mathrm{~mm}$ across, pseudomorphs after primary phenocrysts (probably pyroxene), abundantly distributed in an olive-gray, finegrained matrix commonly rich in carbonates; (2) breccia texture, characterized by fine to coarse bombs, lapilli, and finer pyroclasts of variously textured volcanic rocks packed in a carbonate-rich matrix; and (3) amygdaloidal texture characterized by amygdules typically filled with feldspar, calcite, and actinolite.

The plagioclase in most rocks is oligoclase; in the porphyritic type, amphibole blastophenocrysts are either pale green or colorless with scattered pale-green patches all in optical continuity. Chlorite is common, and brucite was found in two specimens. Quartz is absent or sparse. The pyroclastic rocks are almost invariably schistose, whereas the blastoporphyritic or amygdaloidal rocks commonly are not.

Exposures in the south part of the quadrangle indicate that the lower contact of this member is conformable and locally interfingers with the underlying member. Near the upper contact, metasiltstone, slate, and metalimestone of the overlying metamorphic complex of Conconully are locally interbedded with the metavolcanic rocks, and the contact is therefore gradational.

At exposures east of Mud Lake near the northern boundary of the 
Cave Mountain Formation, interbedding of metamorphosed crystalrich dolomitic pyroclastic rocks with dark-gray phyllite was noted at one locality near the upper contact. The lower contact there is probably faulted.

\section{METAMORPHIC COMPLEX OF CONCONULLY}

All the metamorphic rocks that lie roughly south of a line connecting the eastward-flowing part of Sinlahekin Creek and Flatiron and west of a line connecting Flatiron and Dunn Mountain are mapped as the metamorphic complex of Conconully. In addition, an outlier surrounded by Cave Mountain Formation lies about $1.5 \mathrm{~km}(1 \mathrm{mi})$ east of Dunn Mountain, and a belt $6 \mathrm{~km}$ (4 mi) long, near the southern quadrangle boundary, separates Cave Mountain Formation from the Evans Lake pluton.

The complex is characterized by monotonous lithology and lack of marker beds. Medium- to dark-gray phyllite and metasiltstone constitute about 80 percent of the complex, the remaining 20 percent consisting chiefly of greenstone, thin-bedded metalimestone, and metasandstone in roughly equal proportions. Foliation generally is readily visible in the rocks and is typically parallel with bedding. The complex is probably a few thousand metres thick.

In several places the complex is intruded and metamorphosed by abundant dikes and sills of leucocratic granitic rocks. Primary textures and structures are generally well preserved except near contacts with intrusive rocks, where the metamorphic rocks have been converted to hornfels, schist, and gneiss. Most of the complex is of biotite metamorphic grade. Higher grade rocks occur along contacts with granitic rocks; lower grade rocks are present in the northeastern part of the quadrangle, in a small area (in S. 32, 33, T. 37 N., R. 26 E., and S. 4, 5, T. 36 N., R. 26 E.) bounded on the west by the North Fork of Pine Creek and on the north by faults extending southwest from Flatiron. Bedrock in this small area is exclusively quartz-poor volcanic rock of intermediate composition and feldspathic (volcanic?) wacke. Besides the unusual lithology, this terrane is further distinguished by its low metamorphic grade and by the absence of the otherwise ubiquitous thin interbeds of metasiltsone, phyllite, and metalimestone. Exposures are sparse, and contacts with adjacent rocks were not seen. Unfortunately, the distinctive qualities of this terrane were not recognized in the field, and therefore it is not shown separately on plate 1 .

Rocks of the metamorphic complex in the southwest sector of the quadrangle along Salmon Creek, on Funk Mountain north of Conconully, and on the southernmost spur of Schallow Mountain, are extensively intruded by leucocratic dikes, sills, and irregular masses of granitic rock, mostly alaskite and pegmatite. The intrusions are 
accompanied by a distinct coarsening of grain size in the host rocks. Tiny pink garnets are fairly common in the alaskite and pegmatite and locally also in the host rocks of the complex. Garnet and andalusite are fairly common in aluminous rocks of the complex near pluton contacts, and sillimanite was recognized locally on Funk Mountain, Schallow Mountain, and along Salmon Creek. Diopside occurs locally near plutonic contacts in impure carbonate rocks, and anthophyllite in mafic rocks. Chloritoid and kyanite are present in pelitic rocks a kilometre southwest of the Dunn Mountain pluton. Minute crenulations on the principal foliation surfaces are typical of phyllites of the complex and probably indicate incipient development of a secondary cleavage. Gently plunging minor folds around north- to northwesttrending axes are common.

South of the eastward-flowing part of Sinlahekin Creek, the complex is intruded by abundant blastoporphyritic dikes and sills of felsic and intermediate composition. These intrusive rocks are lithologically similar to those exposed and mapped south of Fish Lake and also to rocks that intrude the Anarchist Group north of eastwardflowing Sinlahekin Creek. Another swarm of similar blastoporphyritic sills and some dikes cut limy phyllite in and near the area (secs. 6, 7, T. 36 N., R. 26 E.) between two outcrops of Tertiary volcanic rocks about $2.5 \mathrm{~km}$ (1.6 mi) southeast of Beeman School. The relict phenocrysts in these dikes and sills are potassium feldspar, however, rather than plagioclase as in the dikes near Sinlahekin Creek.

Lenticular layers of thin-bedded to thin-laminated, medium lightgray to medium dark-gray, fine- to medium-grained metalimestone are present on the east flank of Funk Mountain and on the south flank of Schallow Mountain. The rocks are contorted and thoroughly recrystallized, with tremolite and diopside noted locally in the less pure metalimestone (fig. 5).

Three large mapped bodies of amphibolite and metagabbro and subordinate greenstone intrude the metamorphic complex north of Mud Lake. The rocks show marked variation in texture and grain size and some of the coarsest metagabbro locally contains equant crystals of hornblende as much as a centimetre (0.4 in.) across. The hornblende locally contains a substantial amount of relict augite as cores and irregular patches within the crystals. Near the two southernmost bodies, abundant thin to very thick unmapped layers of amphibolite are interlayered with phyllitic metasiltstone. Amphibolite layers are also abundantly interleaved with phyllite in the general area northwest of the mapped bodies, east of the road, and are especially abundant in the east half of section 12 . In both areas contacts of the amphibolite layers with dark-gray phyllite are poorly exposed but are concordant where observed and locally show banding parallel to 


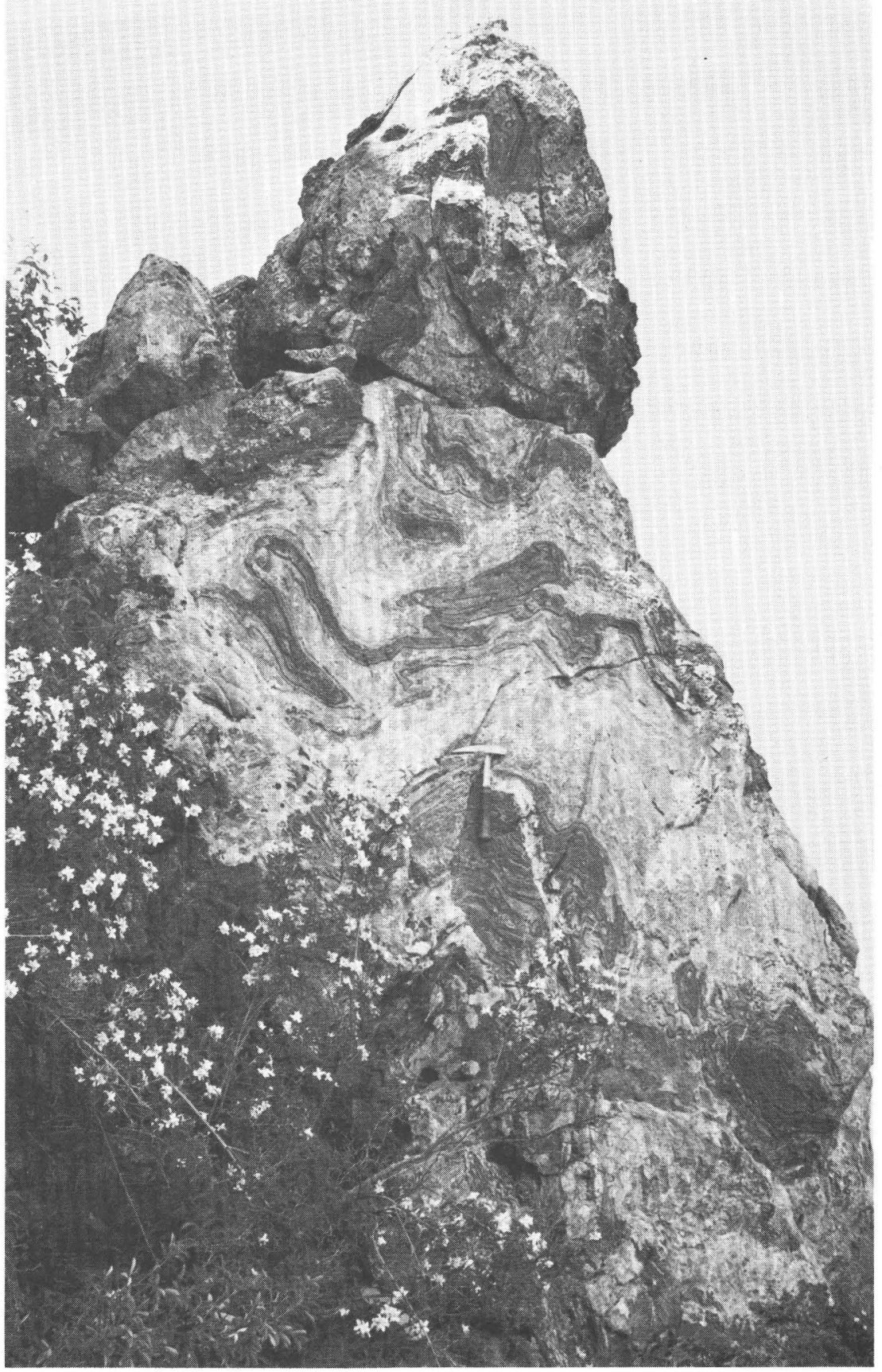

Figure 5.-Contorted bedding in marble lenticle on northeast side of Funk Mountain, in metamorphic complex of Conconully. 
the contacts. The amphibolites are typically massive or poorly cleaved parallel to foliation in the adjacent phyllite. Also sporadically present in both areas are zones of massive breccia that consist of fragments of greenstone, amphibolite, and phyllite, the largest measuring as much as $15 \mathrm{~cm}$ (6 in.) across. The relation of the breccia to the surrounding rocks is unclear, although the absence of planar or linear internal structures, as well as the seemingly random distribution of the breccia indicates that it probably is not tectonic in origin. The breccia is well lithified, and thin-section examination discloses granoblastic actinolite in the matrix, indicating that brecciation occurred before metamorphism ended. The concentration of amphibolite layers in these areas probably represents both sills and lava flows. In addition, their proximity to the large masses of mafic intrusive rocks, and the association of the massive breccia, likely of metavolcanic origin, suggests that the large mapped masses and the adjacent amphibolite-rich terrane are vestiges of a paleovolcanic center that is partly contemporaneous with the surrounding rocks and partly later, but is unquestionably older than regional metamorphism.

The complex of Conconully exposed in the belt between the Cave Mountain Formation and the Evans Lake pluton is mainly phyllite and schist exhibiting biotite-grade metamorphism and is similar in composition to the complex elsewhere. Adjacent to the pluton, however, recrystallization and metamorphic grade increase, and the rocks there are biotite- and hornblende-rich schists and gneisses locally containing garnet, andalusite, and sillimanite.

From field evidence, the complex appears to interfinger at outcrop scale with the underlying Cave Mountain Formation northeast of Mud Lake and also north of the Evans Lake pluton. Along its exposed $6-\mathrm{km}(4 \mathrm{mi})$ length, however, the southern belt transgresses the entire upper (basaltic metavolcanic) member of the Cave Mountain Formation and probably more than half of the next lower (slate and metasiltstone) member as well. In the Dunn Mountain area, the metamorphic complex locally appears to directly overlie the middle (metadolomite and metalimestone) member of the Cave Mountain.

In view of the gradational nature of the contact, implied by the interfingering noted above, the basal contact of the complex of Conconully is probably conformable, and the apparent truncation of the upper members of the Cave Mountain Formation is attributed to primary depositional thinning of that formation.

Perhaps the most troublesome problem associated with the complex of Conconully is the lack of stratigraphic marker horizons and the consequent barrier this presents to any attempt to decipher the internal structure of the unit. The problem becomes immediately 
apparent in an attempt to establish its age.

Although it is clear that the complex overlies the Cave Mountain Formation of Triassic age at several places in the southern part of the area, its relation to the Anarchist Group of Late(?) Permian age in the northwestern part of the area is less certain. The contact of the complex with the Anarchist Group has been placed, with minor exceptions, at the southernmost (presumably the stratigraphically uppermost) bed or lens of chert conglomerate, a rock type characteristic of the Anarchist Group. Except for the chert conglomerate abundantly present within the Anarchist, the Anarchist and complex of Conconully are quite similar. However, chert conglomerate is also present, albeit very sparse, within the northern part of the complex. Because the chert conglomerate beds are discontinuous and erratically distributed within the Anarchist, the mapped contact is accordingly imprecise. At the northeastern margin of the complex, a 4-km $\left(2 \frac{1}{2}-\mathrm{mi}\right)$ segment of the contact is occupied by much sheared metaquartz diorite; farther west, glacial deposits and another granitic unit obscure an additional $6 \mathrm{~km}(4 \mathrm{mi})$ of contact. Map relations suggest that bedding in the Anarchist and the complex is parallel. But the entire Cave Mountain Formation, which intervenes between the two units in the southern part of the quadrangle, is missing at this contact. Moreover, along Sinlahekin Creek the complex is intruded by a small pluton correlated on lithologic grounds with the Loomis pluton, dated at 194 m.y. (Rinehart and Fox, 1972, p. 52). If this correlation is correct, the complex must be at least partly Late Triassic.

The absence of the Cave Mountain Formation between the Anarchist Group and the metamorphic complex of Conconully at the northern margin of the latter suggests that either (1) the Cave Mountain wedges out northward of its type locality, and both it and the overlying Conconully complex successively onlap the Anarchist Group to the north, or (2) the contact between the complex and the Anarchist Group is a fault along which the Cave Mountain has been cut out. The fact that bedding in the complex is conformable with that of the Anarchist near their mutual contact favors the first possibility.

\section{METADIORITE AND META-QUARTZ DIORITE}

An elongate, metamorphosed pluton about $5 \mathrm{~km}^{2}\left(2 \mathrm{mi}^{2}\right)$ in area, including three small satellite masses, lies southeast of Lemanasky Lake in the north-central part of the quadrangle. The pluton cuts the metamorphic complex of Conconully and hence is not older than Late Triassic. It is extensively sheared, foliated, and altered and thus is probably older than Eocene and presumably Triassic or Jurassic. The pluton is composed dominantly of fine- to medium-grained metaquartz diorite and shows xenomorphic-granular texture except in 
local foliated zones. Satellitic dikes and sills commonly cut wallrocks near pluton contacts. The meta-quartz diorite is typically greenish because of abundant chlorite and epidote, and finer grained phases are distinguished from adjacent greenstone by the greater abundance of quartz in the meta-quartz diorite. A typical sample of the metaquartz diorite consists of quartz, oligoclase, hornblende, epidote, and accessory biotite. The oligoclase is extensively sericitized and saussuritized with some relict zoning preserved, and the biotite is chloritized and intimately intergrown with apatite, sphene, and magnetite.

Northeast of Salmon Creek in the southwest corner of the quadrangle, a long narrow pluton of metadiorite and meta-quartz diorite underlies about $1 \frac{1}{2} \mathrm{~km}^{2}\left(1 / 2 \mathrm{mi}^{2}\right)$ along the northeast wall of the canyon. Rocks of the pluton are typically fine- to medium-grained and slightly gneissic. Layering is locally well developed with mediumgrained hornblende-rich layers alternating with fine-grained biotite-rich layers. Much of the unit is pyritic; all rock types are cut by pegmatite dikes. The texture is typically xenomorphic granular but is locally granoblastic, indicating that the rock has been metamorphosed. A typical specimen has a color index of about 25, with mafic minerals about equally divided between hornblende and biotite (largely altered to chlorite); plagioclase is unzoned andesine. A small amount of orthoclase is present as an untwinned variety with an optic axial angle less than $50^{\circ}$. The absence of large potassium feldspar crystals and general absence of layering distinguish this unit from the nearby porphyroblastic granitoid gneiss, which flanks the intervening septum of metamorphic rock on the north.

\section{METAMORPHOSED HYPABYSSAL INTRUSIVE ROCKS IN DIKES AND SMALL MASSES}

\section{TRACHYTOID MONZONITE}

Two small intrusive bodies of blastoporphyritic trachytoid monzonite are located north and west of Mud Lake (in sec. 25, T. 36 N., R. 25 E.); other bodies too small to map are in $\mathrm{NE}^{1 / 4} \mathrm{sec}$. 35 , T. 36 N., R. 25 E., and in $\mathrm{NW}^{1 / 4}$ sec. 19, T. 36 N., R. 26 E. These rocks are characterized by wafer-shaped microcline phenocrysts with length-to-width ratios of $6: 1$ to $10: 1$; the largest blastophenocrysts commonly are about $1 \mathrm{~cm}(0.4 \mathrm{in}$.) acros̀s, but the maximum observed was $4 \mathrm{~cm}(1.6$ in.). Phenocrysts generally show a subparallel alinement that is probably primary, for it is rarely parallel to metamorphic fabric in the adjacent wallrocks. The matrix is typically a fine-grained, partly granoblastic mosaic of plagioclase (albite to andesine), potassium feldspar, and biotite with sparse quartz and hornblende. The matrix 
is also weakly foliated, and the rock is less recrystallized than the enclosing metasedimentary rock. The contacts are locally discordant.

\section{ROCKS OF FELSIC AND INTERMEDIATE COMPOSITION}

A small metadacite body $1 \frac{1}{2} \mathrm{~km}$ south of Fish Lake (in secs. 21, 28, T. 36 N., R. 25 E.) contains abundant equant, euhedral andesine blastophenocrysts that measure as much as $1 \mathrm{~cm}(0.4 \mathrm{in}$.) across in a fine-grained granoblastic mosaic of quartz, feldspar, hornblende, and biotite. Tiny garnet porphyroblasts are present locally. The upper part of this metadacite body is mostly massive blastoporphyry; the lower part consists of blastoporphyritic dikes and sills complexly interleaved with schistose metasedimentary rocks. Except that they lack gneissosity, these meta-igneous rocks are nearly identical to rocks composing a dike swarm in the northeast corner of the quadrangle east of Twin Peaks that intrudes both the Anarchist Group and the metamorphic complex of Conconully.

\section{GRANITOID GNEISS}

Porphyroblastic granitoid gneiss occurs in three areas in the southwestern corner of the Conconully quadrangle: at Happy Hill, Tarheel Hill, and Funk Mountain. At Happy Hill the rocks exposed are medium-grained granodiorite and quartz-monzonite gneiss that are locally porphyroblastic. The phenocrysts are tabular, subhedral potassium feldspar crystals as much as $5 \mathrm{~cm}$ (2 in.) long, lying parallel to the foliation but randomly oriented within the foliation plane. The unit is locally layered, especially near the margins; some layers are probably of metasedimentary origin. The color index of an average specimen is 20 , with biotite as the dominant mafic mineral; hornblende and sphene were recognized at only two localities. The plagioclase is unzoned, complexly twinned oligoclase. In this area the map unit appears to be mainly an orthogneiss.

Gneiss at Tarheel Hill is similar to that at Happy Hill, except that it is nonporphyroblastic and strongly layered; the layers range in composition from alaskite to diorite. Hornblende, rather than biotite, is the dominant mafic mineral. The rocks in this area show a complex history of intrusion, deformation, and later intrusion and probably are mostly or wholly orthogneiss (fig. 6).

On Funk Mountain, gneissic, coarsely porphyritic (or porphyroblastic) quartz monzonite and granodiorite are mixed with and locally cut by fine-grained quartz monzonite. Layering is absent in this area. The color index of an average specimen is about 15 , with hornblende the dominant mafic mineral. The plagioclase is unzoned, complexly twinned oligoclase. 


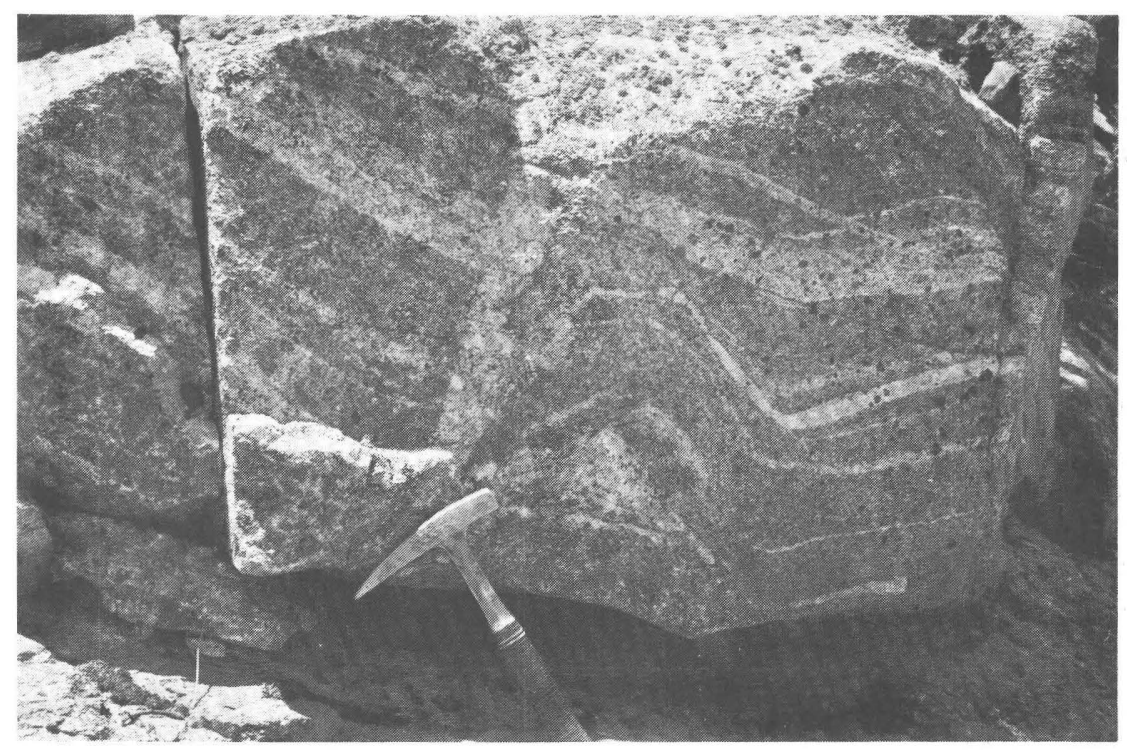

e

Figure 6.-Granitoid gneiss from Tarheel Hill, east of Conconully, showing three ages of aplite/pegmatite dikes. The oldest dikes parallel gneissosity and show open folds; the latter are cut by thin dike, uppermost in photo; this dike is cut by near-vertical dike above head of pick.

\section{PLUTONIC ROCKS}

Analytical data obtained from some of the plutonic rocks described below include chemical, spectrographic, and modal analyses, and potassium-argon age determinations. Localities of specimens analyzed are identified on plate 1 and are listed in tables and illustrations in the paragraphs describing the appropriate plutons. Modal data were obtained from specimens sawed so as to obtain a flat area of 40 to $75 \mathrm{~cm}^{2}$ (6 to $12 \mathrm{in.}{ }^{2}$ ) and then selectively stained for potassium feldspar and plagioclase following the technique described by Norman (1974). A grid of tiny dots was superimposed on each slab with dot spacing chosen so as to cover the entire slab with a minimum of 1,000 points. The mode was obtained by recording which of four constituents-plagioclase, potassium feldspar, quartz, mafic minerals-lay beneath each dot of the superimposed grid.

\section{LOOMIS PLUTON}

Three areas of quartz diorite in the extreme northern part of the Conconully quadrangle, mutually separated by areas of metamorphic rocks, are continuous with the Loomis pluton (Rinehart and Fox, 1972) in the adjacent Loomis quadrangle and Horseshoe Basin quadrangle (Hibbard, 1971). A fourth area, south of Twin Peaks, lithologi- 
cally resembles the Loomis and is assumed to be correlative and possibly continuous with it in the subsurface. The area occupied by the Loomis pluton in the Conconully quadrangle is about $8 \mathrm{~km}^{2}(3$ $\left.\mathrm{mi}^{2}\right)$; the total area of exposure of the pluton is about $180 \mathrm{~km}^{2}(70$ $\mathrm{mi}^{2}$ ).

The pluton as a whole is typically medium grained, equigranular, with hypidiomorphic-granular texture. The pluton, as exposed in the four areas within the Conconully quadrangle, is more varied in composition and texture than the main mass to the north. In the largest area of exposure, along the west wall of Sinlahekin Valley, the rock is especially gneissic and commonly grades to dioritic border zones, which include zones of wallrock intimately injected with both mafic and felsic granitoid rocks. The common mafic minerals are hornblende and biotite, but both show extensive alteration to chlorite and epidote. The plagioclase of a representative specimen is weakly zoned oligoclase. Modes are listed in table 1 and plotted in figure 7 and, when compared with similar data from the Loomis quadrangle, show that in the Conconully quadrangle, the Loomis pluton has less potassium feldspar and a somewhat higher color index than it does in the Loomis quadrangle. The plotted modes in figure 7, nevertheless, generally fall within the field defined by 87 modes representing the pluton in the Loomis quadrangle (in which the pluton occupies about 130 $\left.\mathrm{km}^{2}\left(50 \mathrm{mi}^{2}\right)\right)$.

Potassium-argon ages of hornblende and biotite, determined by Joan C. Engels on a sample from the central part of the pluton in the Loomis quadrangle (Rinehart and Fox, 1972, p. 52), yielded a hornblende age of $194 \pm 6 \mathrm{~m}$.y. and a biotite age of $179 \pm 5 \mathrm{~m}$.y. The hornblende age is considered a minimum but is probably close to the true age of crystallization.

TABLE 1.-Modes, in volume percent, and specific gravity of plutonic rocks [Analyst: M. B. Norman]

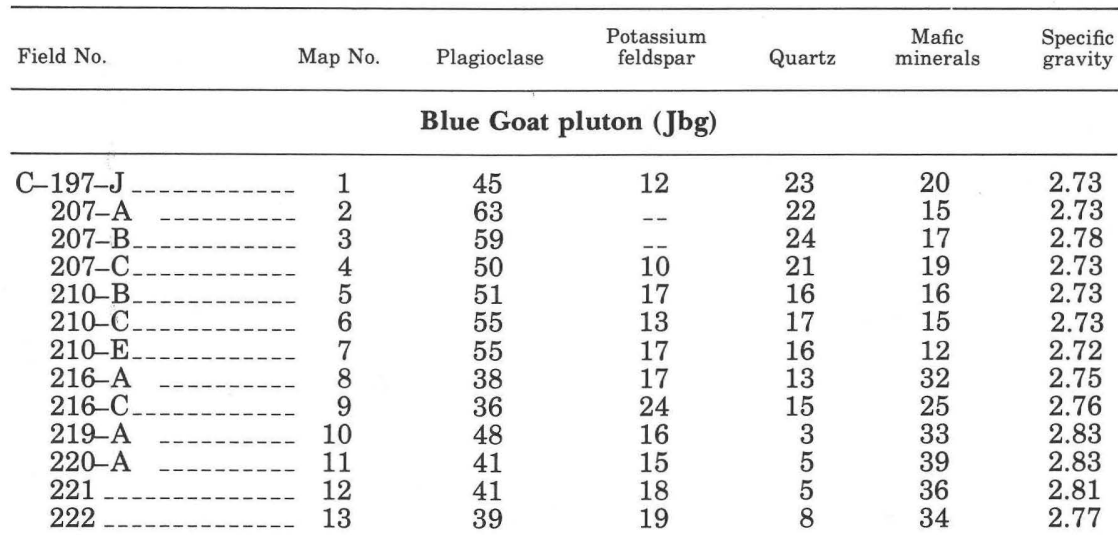


TABLE 1.-Modes, in volume percent, and specific gravity of plutonic rocks-Continued

\begin{tabular}{|c|c|c|c|c|c|c|}
\hline Field No. & Map No. & Plagioclase & $\begin{array}{l}\text { Potassium } \\
\text { feldspar }\end{array}$ & Quartz & $\begin{array}{c}\text { Mafic } \\
\text { minerals }\end{array}$ & $\begin{array}{l}\text { Specific } \\
\text { gravity }\end{array}$ \\
\hline \multicolumn{7}{|c|}{ Blue Goat pluton (Jbg) - Continued } \\
\hline 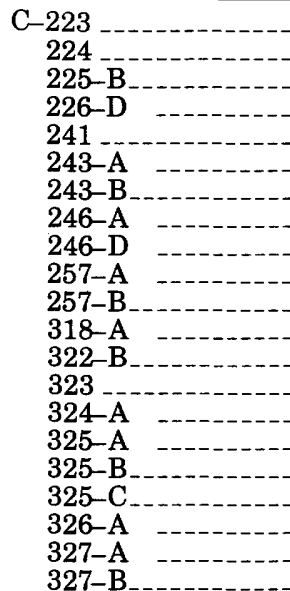 & 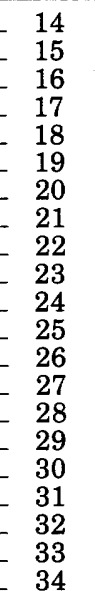 & $\begin{array}{l}35 \\
37 \\
39 \\
41 \\
36 \\
52 \\
48 \\
51 \\
54 \\
53 \\
55 \\
58 \\
57 \\
58 \\
51 \\
56 \\
59 \\
57 \\
46 \\
50 \\
56\end{array}$ & $\begin{array}{l}23 \\
18 \\
16 \\
22 \\
22 \\
12 \\
12 \\
12 \\
12 \\
12 \\
15 \\
12 \\
11 \\
15 \\
19 \\
17 \\
14 \\
14 \\
17 \\
15 \\
18\end{array}$ & $\begin{array}{r}8 \\
11 \\
9 \\
5 \\
13 \\
16 \\
20 \\
20 \\
18 \\
9 \\
18 \\
15 \\
16 \\
12 \\
18 \\
17 \\
14 \\
15 \\
15 \\
17 \\
16\end{array}$ & $\begin{array}{l}34 \\
34 \\
36 \\
32 \\
29 \\
20 \\
20 \\
17 \\
16 \\
26 \\
12 \\
15 \\
16 \\
15 \\
12 \\
10 \\
13 \\
14 \\
22 \\
18 \\
10\end{array}$ & $\begin{array}{l}2.81 \\
2.80 \\
2.84 \\
2.70 \\
2.78 \\
2.74 \\
2.75 \\
2.73 \\
2.72 \\
2.78 \\
2.70 \\
2.72 \\
2.74 \\
2.74 \\
2.69 \\
2.70 \\
2.70 \\
2.71 \\
2.75 \\
2.72 \\
2.69\end{array}$ \\
\hline
\end{tabular}

Fine-grained granodiorite dikes intruded into Blue Goat pluton southeast of Bald Butte

\begin{tabular}{rrrrrrrr}
\hline C-356-A & - & 35 & 61 & 12 & 21 & 6 & 2.64 \\
$357-A$ & ------ & 36 & 56 & 18 & 19 & 7 & 2.68 \\
$357-B$ & $-\cdots---$ & 37 & 52 & 14 & 31 & 3 & 2.65 \\
\hline
\end{tabular}

\section{Loomis pluton $(\mathrm{K} l)$}

\begin{tabular}{|c|c|c|c|c|c|c|}
\hline 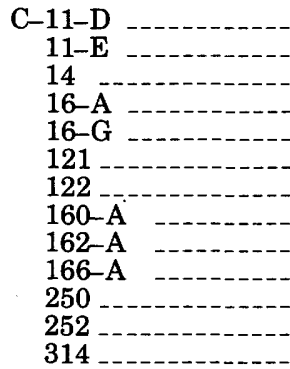 & $\begin{array}{r}1 \\
2 \\
3 \\
4 \\
5 \\
6 \\
7 \\
8 \\
9 \\
10 \\
11 \\
12 \\
13\end{array}$ & $\begin{array}{l}56 \\
55 \\
60 \\
62 \\
57 \\
57 \\
47 \\
58 \\
53 \\
58 \\
51 \\
55 \\
54\end{array}$ & $\begin{array}{l}\leqslant 1 \\
\sim 1 \\
\operatorname{Tr} . \\
\operatorname{Tr} . \\
<1 \\
7 \\
8 \\
\operatorname{Tr} . \\
<1 \\
\operatorname{Tr} . \\
\operatorname{Tr} . \\
\operatorname{Tr} . \\
\operatorname{Tr}\end{array}$ & $\begin{array}{l}24 \\
26 \\
22 \\
20 \\
25 \\
23 \\
31 \\
29 \\
28 \\
29 \\
23 \\
19 \\
25\end{array}$ & $\begin{array}{l}19 \\
19 \\
18 \\
18 \\
18 \\
13 \\
14 \\
13 \\
18 \\
13 \\
26 \\
26 \\
21\end{array}$ & $\begin{array}{r}2.73 \\
2.76 \\
2.80 \\
2.79 \\
2.77 \\
2.75 \\
2.76 \\
2.76 \\
2.77 \\
2.79 \\
2.81 \\
2.81 \\
2.76\end{array}$ \\
\hline
\end{tabular}

Aeneas Creek pluton (KJa)

\begin{tabular}{|c|c|c|c|c|c|c|}
\hline C-123 & 1 & 39 & 26 & 25 & 10 & 2.68 \\
\hline 124 & 2 & 37 & 26 & 25 & 13 & 2.69 \\
\hline $126-\mathrm{C}_{2}$ & 3 & 53 & 10 & 18 & 19 & 2.74 \\
\hline 127 & 4 & 45 & 20 & 21 & 14 & 2.71 \\
\hline $128-\mathrm{C}$ & 5 & 37 & 29 & 22 & 12 & 2.69 \\
\hline $129 \ldots$ & 6 & 41 & 20 & 24 & 15 & 2.69 \\
\hline 130 & 7 & 40 & 23 & 26 & 11 & 2.69 \\
\hline 139 & 8 & 38 & 27 & 25 & 10 & 2.67 \\
\hline $173-\mathrm{A}$ & 9 & 39 & 25 & 26 & 10 & 2.68 \\
\hline
\end{tabular}


TABLE 1.-Modes, in volume percent, and specific gravity of plutonic rocks-Continued

\begin{tabular}{|c|c|c|c|c|c|c|}
\hline Field No. & Map No. & Plagioclase & $\begin{array}{l}\text { Potassium } \\
\text { feldspar }\end{array}$ & Quartz & $\begin{array}{c}\text { Mafic } \\
\text { minerals }\end{array}$ & $\begin{array}{l}\text { Specific } \\
\text { gravity }\end{array}$ \\
\hline \multicolumn{7}{|c|}{ Evans Lake pluton (KJep, KJef) } \\
\hline 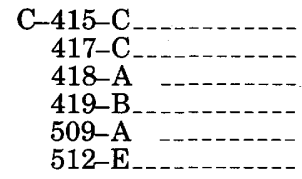 & $\begin{array}{l}1 \\
2 \\
3 \\
4 \\
5 \\
6\end{array}$ & $\begin{array}{l}37 \\
38 \\
52 \\
46 \\
51 \\
47\end{array}$ & $\begin{array}{l}29 \\
21 \\
13 \\
16 \\
10 \\
11\end{array}$ & $\begin{array}{r}26 \\
28 \\
12 \\
23 \\
13 \\
4\end{array}$ & $\begin{array}{r}8 \\
13 \\
23 \\
15 \\
26 \\
38\end{array}$ & $\begin{array}{l}2.66 \\
2.68 \\
2.76 \\
2.69 \\
2.76 \\
2.81\end{array}$ \\
\hline
\end{tabular}

Dunn Mountain pluton (dm)

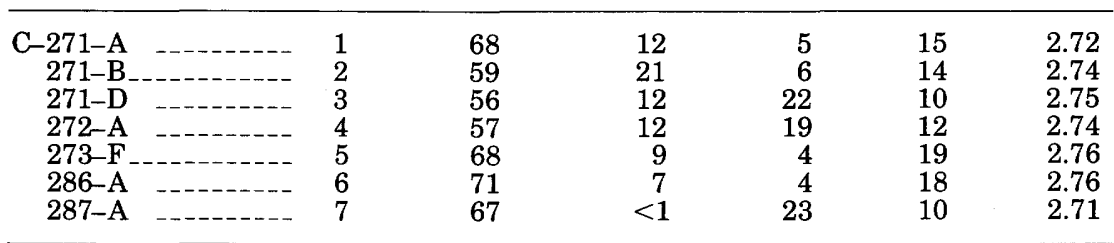

Quartz monzonite west of Salmon Creek (Kqs)

\begin{tabular}{|c|c|c|c|c|c|c|}
\hline $\mathrm{C}-296-\mathrm{A}$ & 8 & 37 & 29 & 30 & 4 & 2.62 \\
\hline \multicolumn{7}{|c|}{ Porphyroblastic granitoid gneiss ( kgn) } \\
\hline $\begin{array}{l}\text { C-259-B } \\
\text { (Funk Mtn.) } \\
\quad 267-\mathrm{E}\end{array}$ & 9 & 58 & 25 & 4 & 13 & 2.69 \\
\hline $\begin{array}{l}\text { (Tarheel Hill) } \\
267-\mathrm{F}\end{array}$ & 10 & 55 & 20 & 5 & 20 & 2.74 \\
\hline $\begin{array}{l}\text { (Tarheel Hill) ----- } \\
297-\mathrm{B}\end{array}$ & 11 & 44 & 30 & 1 & 25 & 2.77 \\
\hline (Happy Hill) - & 12 & 51 & 10 & 19 & 20 & 2.76 \\
\hline \multicolumn{7}{|c|}{ Meta-quartz diorite southeast of Lemanasky Lake ( $\mathrm{k}$ mq) } \\
\hline $\begin{array}{r}\mathrm{C}-133-\mathrm{F} \\
138-\mathrm{B}\end{array}$ & $\begin{array}{l}13 \\
14\end{array}$ & $\begin{array}{l}61 \\
65\end{array}$ & $\begin{array}{l}\text { Tr. } \\
\text { Tr. }\end{array}$ & $\begin{array}{l}24 \\
21\end{array}$ & $\begin{array}{l}15 \\
14\end{array}$ & $\begin{array}{l}2.80 \\
2.80\end{array}$ \\
\hline
\end{tabular}

\section{BLUE GOAT PLUTON}

The Blue Goat pluton, largest within the quadrangle, is mainly granodiorite and occupies about $40 \mathrm{~km}^{2}\left(15 \mathrm{mi}^{2}\right)$ along southern Sinlahekin Valley; all but a small area less than $1 \mathrm{~km}^{2}$ lies within the quadrangle. The rocks are typically medium grained and moderately but inconspicuously porphyritic and contain subhedral, somewhat poikilitic potassium feldspar phenocrysts as much as $2 \mathrm{~cm}(0.8 \mathrm{in}$.) long, but generally less than $1 \mathrm{~cm}(0.4 \mathrm{in}$.). Foliation is fairly common and typically parallel to wallrock contacts. The contacts are generally sharp and concordant, bordered by dikes and sills of granodiorite 


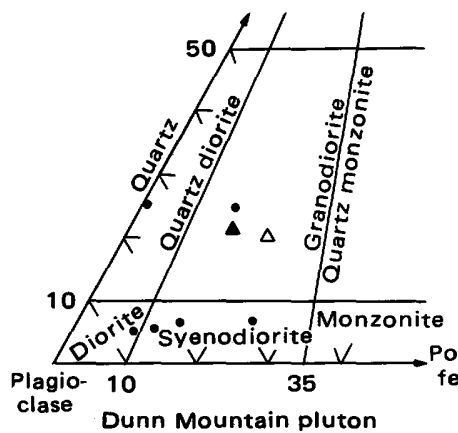

EXPLANATION

Average of entire pluton

\section{0}

Average of nonporphyritic phase

\section{Average of porphyritic} phase

\section{otassium} feldspar

clase Dunn Mountain pluton

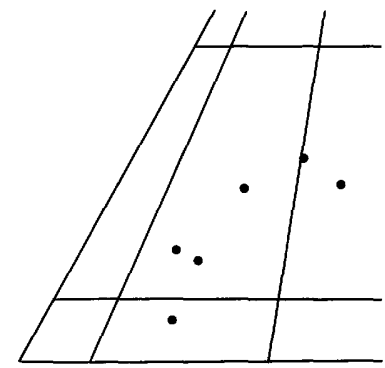

Evans Lake pluton

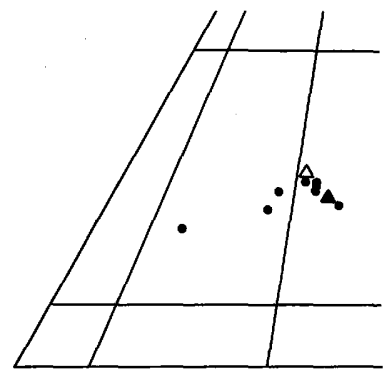

Aeneas Creek pluton

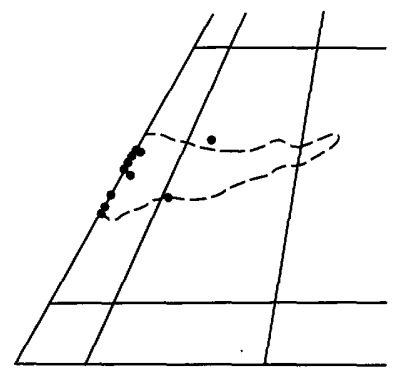

Loomis pluton

\section{EXPLANATION}

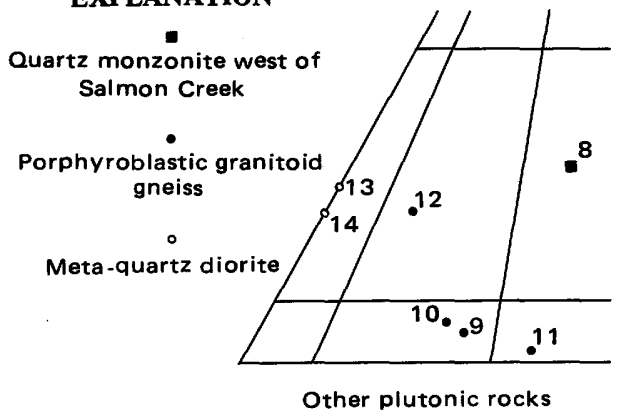

FIGURE 7.-Modal plots, on quartz-potassium feldspar-plagioclase diagrams, of plutonic rocks in Conconully quadrangle. Numbers refer to specific modes in table of modal analyses. Modes and norms of chemically analyzed specimens indicated by solid and open triangles, respectively. Circled dots in Blue Goat diagram indicate nonporphyritic rocks. Dashed line on Loomis diagram outlines area occupied by 87 modes representing pluton in Loomis quadrangle, adjacent on north. 
cutting the adjacent, somewhat coarsened metamorphic rock. Toward the contact, the granodiorite becomes darker and more gneissic, the abundance of mafic inclusions increases, and the abundance and size of potassium feldspar phenocrysts decrease. Thin aplite dikes are common throughout the pluton, and southeast of Bald Butte numerous dikes of fine-grained, nonporphyritic granodiorite and quartz monzonite with a low color index cut the pluton. The texture is hypidiomorphic-granular (nearly xenomorphic-granular), and the rocks commonly appear somewhat granulated and recrystallized; a few remnants of mortar structure were seen. The plagioclase is typically zoned oligoclase, and the color index averages 22. Ratios of biotite to hornblende generally are less than 1:1 and are as low as $1: 10$ in the more mafic phases.

Modes of the pluton (table 1), as plotted in figures 7 and 8 bring out some unusual features: (1) nonporphyritic rocks, when separately identified in figure 7 , define a group separate from and richer in potassium feldspar than the other rocks; (2) in figure 8 these same rocks almost all lie nearest the southeast margin of the pluton and in a satellite mass; (3) figure 8 also shows that this group is highest in specific gravity and color index (percentage of dark minerals), the latter features perhaps better emphasized in figure 9 .

In the light of these data it appears possible that the nonporphyritic suite at the southeastern part of the pluton, including the satellite mass, represents a separate pluton. If a separate pluton does not exist, the petrologic trend of the nonporphyritic suite toward the potassium feldspar corner of the diagram (fig. 7), but with a parallel increase in color index, is unusual among trends in calc-alkalic plutons.

The sample analyzed (table 2) was taken from the porphyritic phase of the pluton, and its mode is very similar to the average composition of that phase (fig. 7). Both the analysis and the norm compare closely to Nockolds' (1954, p. 1014) hornblende-biotite granodiorite.

The pluton was probably emplaced as a fluid magma as suggested by: (1) locally discordant contacts, (2) presence at a few localities of mafic inclusions whose preserved structures appear to have been rotated with respect to nearby wallrock structure, (3) dikes and sills of granodiorite that penetrate wallrock, (4) marked indication of concentric zoning with respect to dark mineral content and specific gravity (fig. 8).

Notwithstanding local discordances, however, the map shows pronounced parellelism between plutonic contacts and wallrock foliation. In fact, the configuration of the contact suggests the pluton is a rather thick, tabular mass that dips moderately west, and whose 

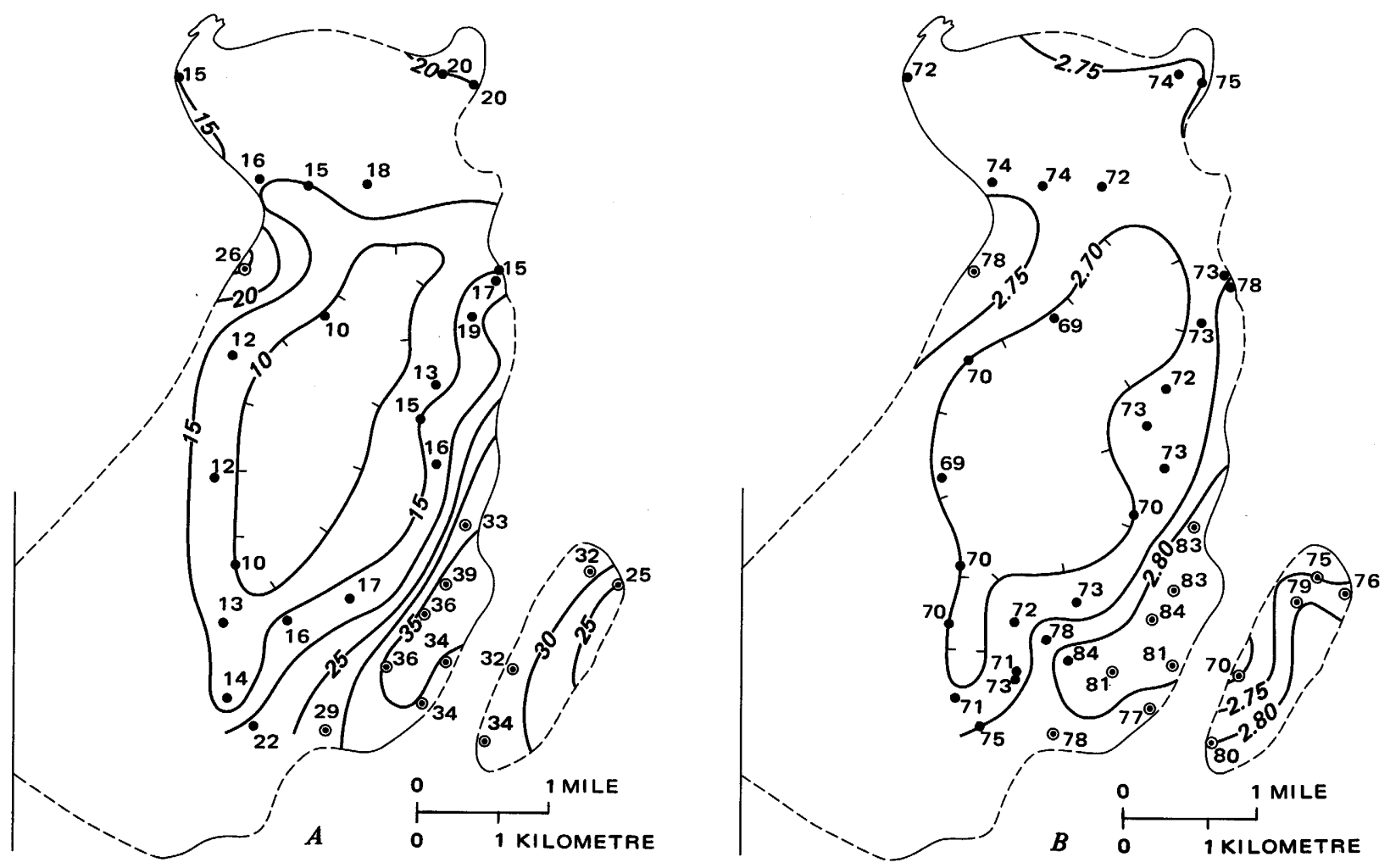

FIGURE 8.-Isopleth maps of Blue Goat pluton. $A$, Color index (percentage of dark minerals). B, Specific gravity. Circled localities indicate nonporphyritic rocks. On $B$, values at all localities abbreviated by omitting decimal point and the antecedent "2." 


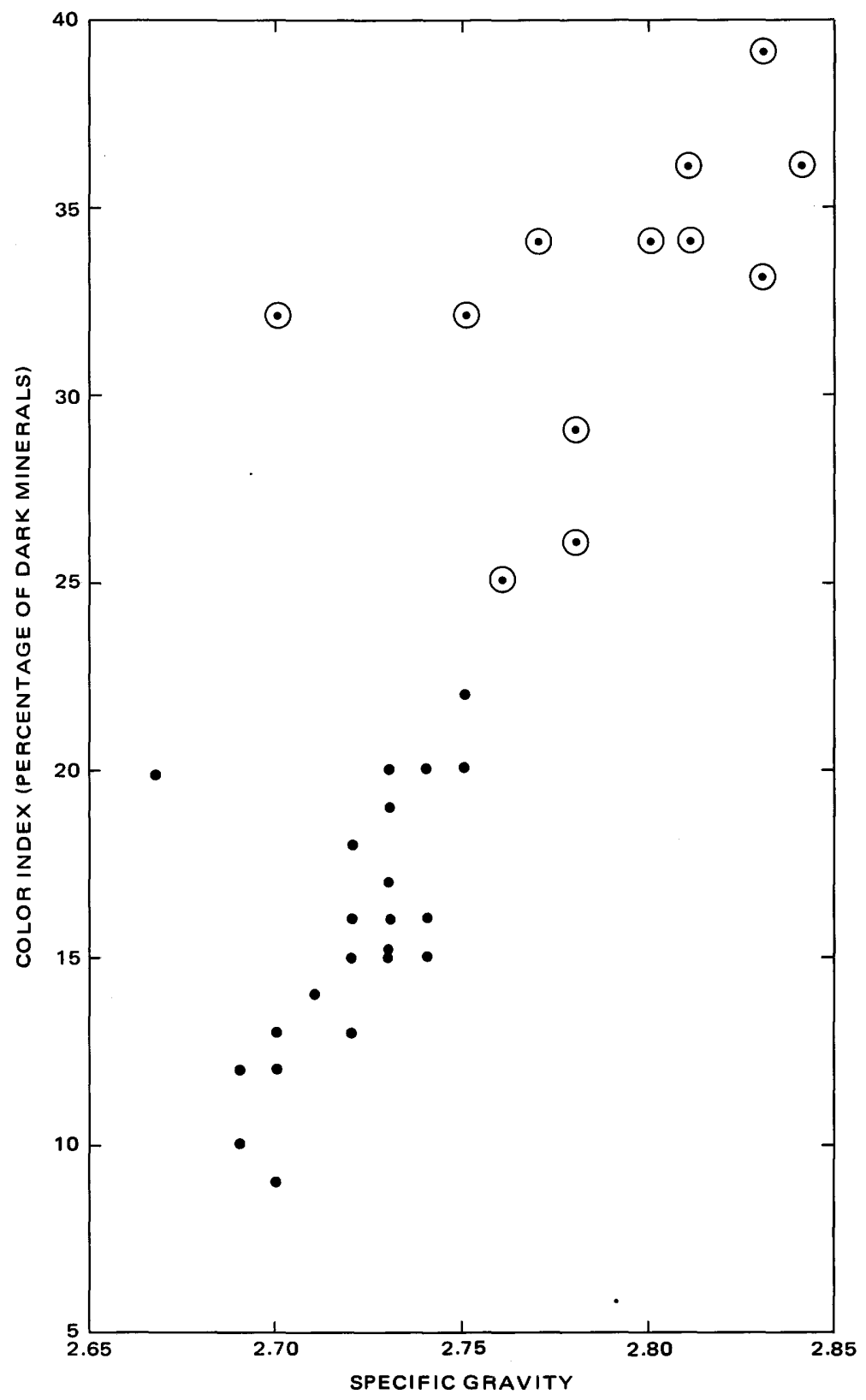

FIGURE 9.-Correlation of color index and specific gravity of rocks from the Blue Goat pluton. Circled points are nonporphyritic rocks. 
TABLE 2.-Chemical and spectrographic analyses and CIPW norms and modes of granitic rocks

[Analysts for chemical analyses: P. Elmore, L. Artis, H. Smith, J. Glenn, J. Kelsey. Analyses by the rapid method of Shapiro and Brannock (1956), supplemented by atomic absorption. Analyst for spectrographic analyses: R. E. Mays. Results are identified with numerical brackets whose boundaries are $1.2,0.83,0.56,0.38,0.26,0.18,0.12$ but are reported arbitrarily as midpoints of these brackets: $1 ., 0.7,0.5,0.3,0.2,0.15,0.1$. The precision of a reported value is approximately plus or minus one bracket at 68 percent, or two brackets at 95 percent confidence. Looked for but not found: Ag, As, Au, B, Bi, Cd, Ce, Ge, Hf, In, La, Li, Mo, Pd, Pt, Re, Sb, Sn, Ta, Te, Th, Tl, U, W, $\mathrm{Zn}$. Analyst for modes: M. B. Norman. Measured on stained rock slabs; proportions of biotite and hornblende estimated from thin sections]

\begin{tabular}{ccc} 
C-139 & $\begin{array}{c}\text { C-246-D } \\
\text { Quartz monzonite, } \\
\text { Aeneas Creek pluton }\end{array}$ & $\begin{array}{c}\text { C-272-A } \\
\text { Granodionite, } \\
\text { Blue Goat pluton }\end{array}$ \\
\hline
\end{tabular}

\section{Chemical analyses}

\begin{tabular}{|c|c|c|c|}
\hline 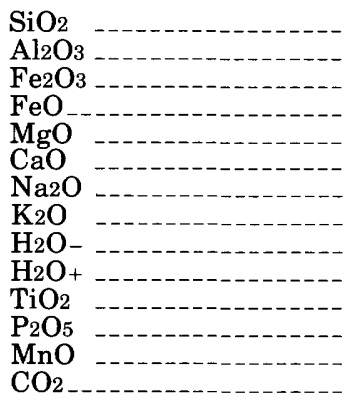 & $\begin{array}{c}69.1 \\
15.2 \\
1.2 \\
1.9 \\
1.2 \\
2.4 \\
3.3 \\
3.9 \\
.00 \\
1.0 \\
.42 \\
.14 \\
.05 \\
.08\end{array}$ & $\begin{array}{r}65.4 \\
17.0 \\
1.5 \\
2.0 \\
1.4 \\
4.2 \\
4.1 \\
2.8 \\
.00 \\
.79 \\
.38 \\
.20 \\
.08 \\
.09\end{array}$ & $\begin{array}{c}63.8 \\
17.6 \\
1.2 \\
3.1 \\
1.2 \\
4.7 \\
3.7 \\
3.0 \\
.00 \\
.81 \\
.50 \\
.22 \\
.13 \\
<.05\end{array}$ \\
\hline Total & 99.89 & 99.94 & 99.96 \\
\hline
\end{tabular}

Spectrographic analyses for minor elements, in ppm

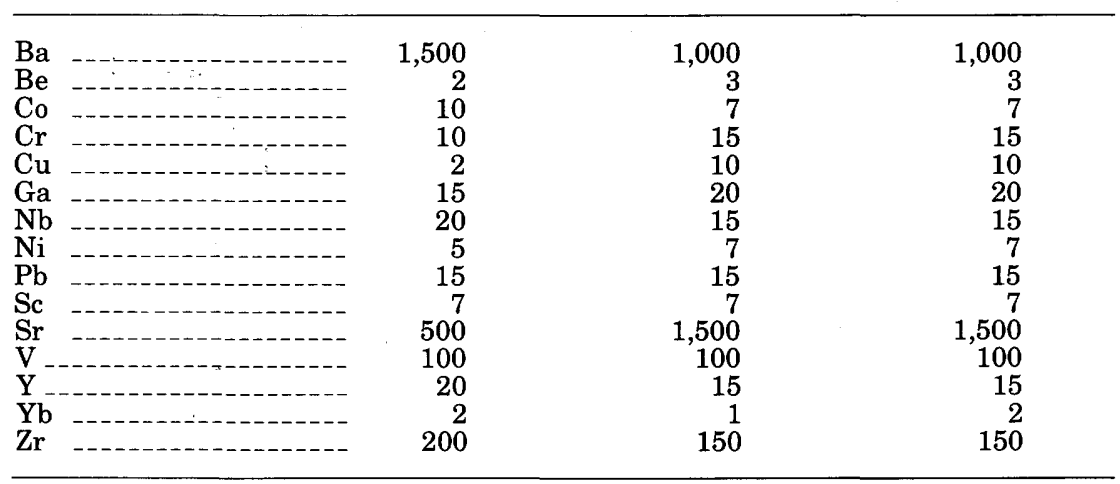

CIPW norms (weight percent)

\begin{tabular}{lrrr}
\hline q & & & \\
c -19.9 & 19.6 & 17.8 \\
or $-1 .-1.9$ & 1.5 & .3 \\
\end{tabular}


TABLE 2.-Chemical and spectrographic analyses and CIPW norms and modes of granitic rocks-Continued

\begin{tabular}{|c|c|c|c|c|}
\hline & & $\begin{array}{c}\text { C-139 } \\
\text { Quartz monzonite, } \\
\text { Aeneas Creek pluton }\end{array}$ & $\begin{array}{c}\mathrm{C}-246-\mathrm{D} \\
\text { Granodiorite, } \\
\text { Blue Goat pluton }\end{array}$ & $\begin{array}{c}\text { C-272-A } \\
\text { Granodiorite, } \\
\text { Dunn Mountain pluton }\end{array}$ \\
\hline \multicolumn{5}{|c|}{ CIPW norms (weight percent)-Continued } \\
\hline $\begin{array}{l}\text { ab } \\
\text { an } \\
\text { en } \\
\text { fs } \\
\text { mt } \\
\text { il } \\
\text { ap }\end{array}$ & 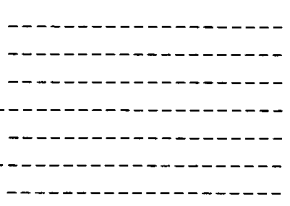 & $\begin{array}{r}28.3 \\
11.1 \\
3.0 \\
1.9 \\
1.8 \\
.8 \\
.3\end{array}$ & $\begin{array}{r}35.0 \\
19.7 \\
3.5 \\
2.0 \\
2.2 \\
.7 \\
.5\end{array}$ & $\begin{array}{r}31.6 \\
22.1 \\
3.0 \\
4.2 \\
1.8 \\
1.0 \\
.5\end{array}$ \\
\hline & Total & 99.9 & 100.0 & 100.2 \\
\hline
\end{tabular}

Modes (volume percent)

\begin{tabular}{|c|c|c|c|c|}
\hline Quartz & 25 & 18 & 19 & \\
\hline $\begin{array}{l}\text { microcline } \\
\text { Plagioclase } \\
\text { An (range) } \\
\text { Biotite } \\
\text { Hornblende } \\
\text { Other }\end{array}$ & $\begin{array}{c}27 \\
38 \\
\begin{array}{c}(20-40) \\
(\sim 5) \\
(\sim 5) \\
<1\end{array} \quad 10\end{array}$ & $\left.\begin{array}{c}12 \\
54 \\
(20-55) \\
(\sim 5) \\
(\sim 11) \\
<1\end{array}\right\} 16$ & $\left.\begin{array}{c}12 \\
57 \\
\sim 35 \\
(\sim 7) \\
(\sim 5) \\
<1\end{array}\right\}$ & 12 \\
\hline Total & 100 & 100 & 100 & \\
\hline
\end{tabular}

southern contact probably dips moderately north. The dip direction of the northern contact is obscure, but it is probably steep. The local discordance, yet general concordance, of the pluton suggests that the country rocks had been deformed and metamorphosed prior to emplacement of the pluton and probably exerted considerable influence on its final shape.

Potassium-argon ages of biotite and hornblende, $99.3 \pm 3.0$ m.y. and 141.8 \pm 8.2 m.y. (table 3), respectively, from a sample in the southcentral part of the pluton, show a marked discordance that may be related to the abundant dikes of fine-grained granodiorite and quartz monzonite that cut the pluton about $1.5 \mathrm{~km}(1 \mathrm{mi})$ north of the sample locality. Similar dikes and sills are especially abundant in the metamorphic rocks of Funk Mountain, adjacent to the southern contact of the pluton, and to the west in the adjacent Tiffany Mountain quadrangle. The wide distribution and abundance of the dikes and sills probably mark a significant intrusive episode that doubtless was accompanied by heating of the country rock, perhaps sufficiently to have reduced the apparent ages of both minerals; biotite shows the greater reduction owing to its greater vulnerability to argon loss. 
TABLE 3.-Mineral ages of some granitic rocks from the Conconully quadrangle [Age determinations by Joan C. Engels]

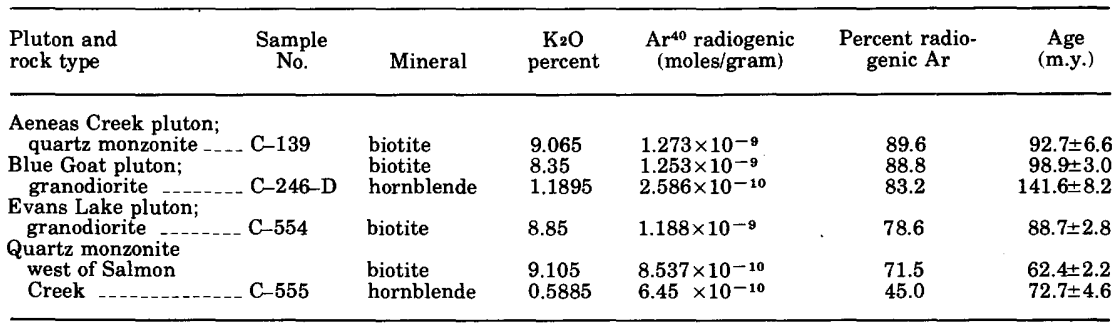

Thus the hornblende age provides a minimum age for crystallization of the pluton, although the true age may be substantially greater.

\section{DUNN MOUNTAIN PLUTON}

The Dunn Mountain pluton and probable correlative masses comprise four discrete bodies, located in the southwestern quarter of the quadrangle, totaling about $5 \mathrm{~km}^{2}\left(2 \mathrm{mi}^{2}\right)$ in area. The unit is named for a low but prominent mountain in the northeasternmost mass. The rocks are fine- to medium-grained, equigranular granodiorite, syenodiorite, diorite, and quartz diorite (fig. 7). The stock at Dunn Mountain, although varied, probably averages mafic granodiorite in composition; the specimen analyzed (table 2 ) is considered typical, and its mode compares reasonably well with Nockolds" "average granodiorite" (1954, p. 1014). At Dunn Mountain, the rocks are typically massive, but elsewhere they are locally gneissic. Plagioclase is typically oligoclase, and mafic minerals, which average 14 percent of the mode, are chiefly biotite and hornblende in roughly equal proportions. Contacts with wallrocks where observed are mostly discordant, but at one exceptionally good exposure on the south side of Dunn Mountain, the wallrock contact is concordant and dips gently south. An intrusion breccia was observed at an exposure near that locality, and in several places the contact is marked by decrease in grain size of the granitic rock, suggestive of chilling. Contacts of the other granitic masses are bordered by numerous dikes and sills intruded into the adjacent host rocks. The age of the pluton and its satellitic masses relative to other plutonic rocks in the quadrangle is not known.

\section{AENEAS CREEK PLUTON}

The Aeneas Creek pluton is composed of quartz monzonite and granodiorite and occupies about $4 \mathrm{~km}^{2}\left(1.5 \mathrm{mi}^{2}\right)$ in the northeast part of the quadrangle. The two dioritic masses occupy about $1.5 \mathrm{~km}^{2}(0.5$ $\mathrm{mi}^{2}$ ) and are considered to be early mafic phases of the Aeneas Creek, although the southernmost mass is clearly intruded by leucocratic 
rocks of the pluton. Leucocratic rocks composing the pluton are fairly homogeneous, medium grained, fairly equigranular with hypidiomorphic-granular texture, and massive. Contacts typically are sharp and discordant and are commonly marked by zones of numerous dikes and sills of aplite and pegmatite. Biotite intergrown with less abundant hornblende, along with secondary chlorite, together average 13 percent of the rock. The plagioclase typically is zoned oligoclase. Modes of a representative suite of specimens are plotted in figure 7 and listed in table 1 . The chemical analysis and norm of one of these specimens are given in table 2 . The analysis compares closely with that of "average adamellite" of Nockolds (1954, p. 1014).

Intrusion of the pluton as a fluid magma is indicated by local wallrock inclusions and by contacts that, although at map scale are typically parallel to foliation in wallrocks, are locally discordant. Geothermal gradients were probably gentle at the time of intrusion for grain sizes in rocks for several metres on both sides of the contacts seem to show little variation relative to distance from the contact. Evidence of mechanical effects of intrusion is scanty, but some flattening of fragments in sharpstone conglomerate of the Anarchist Group was noted close to the contact in a few places along the northeast border of the pluton. The elongate shape of the pluton was probably imposed by preexisting structures in the metamorphic rocks, judging by general parallelism between the long axis of the pluton and the contact between the Anarchist and the metamorphic complex of Conconully, and the structures internal to these metamorphic units.

Although the diorite mass along the southern contact of the Aeneas Creek pluton is clearly intruded by leucocratic rocks of the pluton, it is here considered to be an earlier but possibly related rock, partly because of its position along the contact. Its age is doubtless closer to that of the Aeneas Creek pluton than it is, for example, to the Loomis pluton because rocks of somewhat similar composition associated with the Loomis typically show evidence of deformation; such features are absent in the diorite mass. Though probably dioritic in average composition, the mass consists of rocks ranging from quartz diorite to gabbro and shows equally wide variations in texture. The dioritic mass of comparable size immediately northwest of the pluton is similar in composition, texture, and lack of deformation, and it, too, is considered to be an early mafic phase of the Aeneas Creek pluton. The mapped body of felsic granitic rock in the center of this mafic mass, though varied, contains rock types similar in appearance and composition to those of the Aeneas Creek pluton, and in addition, the leucocratic rocks are partly gradational with the surrounding dioritic rocks. 
A potassium-argon biotite age determination (table 3) was made on a sample collected near the center of the pluton and yielded an age of $92.7 \pm 6.6 \mathrm{~m} . \mathrm{y}$. Unfortunately, it was not possible to obtain a sufficiently pure hornblende separation for an age determination on that mineral, and the biotite age must therefore be considered a minimum age for the pluton.

\section{GRANITIC ROCKS IN DIKES AND SMALL MASSES}

Granitic rocks in dikes and small masses of varied or unknown age are divided into three units: (1) aplite, alaskite, and pegmatite; (2) felsic and intermediate rocks; (3) mafic rocks.

Bodies of aplite, alaskite, and pegmatite occur in the southwest corner of the quadrangle; within these bodies, all three lithologic types intergrade. The rocks are typically crosscutting and without directional fabric; some are zoned and have coarser grained cores. Megascopically, they appear to be composed of quartz, potassium feldspar, and plagioclase in approximately equal proportions, and many are dotted with tiny pink garnets.

The felsic and intermediate unit comprises a host of varied, mostly hypabyssal fine- to medium-grained rocks ranging in composition from quartz monzonite to granodiorite but including some aplite, alaskite, and pegmatite. Rocks of this type intrude the metamorphic rocks northeast of Conconully on Funk Mountain and the southern part of Schallow Mountain in such abundance that they cannot be shown separately on plate 1 but are distinguished by an overprinted pattern. The unit also includes an apparently contaminated or hybridized cupola of a buried pluton at Mud Lake (sec. 24, T. 36 N., R. 25 E.). Biotite is the chief mafic mineral; pyriboles are generally absent. An unusual body of crushed, albitized, and bleached granodiorite, superficially resembling alaskite, is exposed at the eastern boundary of the quadrangle in sec. 12, T. 36 N., R. $26 \mathrm{E}$. The granodiorite is cut by a boxwork of fluorite-bearing veinlets.

Mapped bodies of mafic rocks, exclusive of the early mafic phase of the Aeneas Creek pluton, consist of three small masses, one $3 \mathrm{~km}(2$ mi) east of Conconully Reservoir that forms a tiny "island" in glacial drift; another in the eastward-trending canyon of Sinlahekin Creek; a third in the east canyon wall of the north-northeast-trending canyon of the same creek. The northwesternmost mass is varied, but a typical specimen is medium-grained massive hornblende-biotite diorite. The northeastern body is concentrically zoned from a medium-grained hornblende diorite border zone to a medium-grained granodioritic core. This gradational characteristic of the small body gives it a marked resemblance to the large mafic mass northwest of, and correlated with, the Aeneas Creek pluton; hence, the small body may be a cupola formed of early Aeneas Creek magma. The tiny "island" east 
of Conconully Reservoir is medium-grained porphyritic pyroxene diorite.

\section{EVANS LAKE PLUTON}

The Evans Lake pluton comprises two distinct phases: a finegrained dioritic phase and a medium- to coarse-grained porphyritic granodioritic and quartz monzonitic phase, together occupying about $8 \mathrm{~km}^{2}\left(3 \mathrm{mi}^{2}\right)$ in the southern part of the quadrangle. The pluton occupies an additional area of approximately $20 \mathrm{~km}^{2}\left(8 \mathrm{mi}^{2}\right)$ south of the quadrangle boundary which was not examined during the present study.

Along most of its extent in the quadrangle, the contact of the pluton with metamorphic rocks appears concordant, dipping southwest moderately to steeply; at the western limit of exposure the attitude of the contact and the relation of the contact to wallrocks are obscure. The porphyritic phase is distinguished by abundant, blocky potassium feldspar phenocrysts, as much as $5 \mathrm{~cm}$ (2 in.) long, that locally show weak planar orientation. Groundmasses of both phases are commonly xenomorphic-granular with unzoned plagioclase showing bent twin lamellae, locally accompanied by mortar structure, suggesting cataclasis and recrystallization. Considerable compositional variation is shown by the scatter of the modes (table 1) plotted in figure 7 . The color index likewise shows a wide range and varies directly with the amount of hornblende.

Misch $(1949 a$, p. 687,691$)$ briefly referred to the Evans Lake pluton as a granitized body and believed that it occupies the core of a syncline. He cited as evidence the fact that the pluton contains "relict lenses of amphibolite and biotite schist [that] can still be correlated to the normal stratigraphic sequence in the syncline***" (p. 691). It is possible that the pluton occupies the core of a syncline, for although we have not examined the southern border, the northern contact of the pluton shows marked concordance with the adjacent southwarddipping homoclinal wallrock sequence. However, we have been unable to correlate any of the lenses of amphibolite and schist included within the pluton with any specific units in the wallrock sequence.

The history of the pluton appears to be complex, and study of the entire mass is required before the nature of its origin and emplacement can be elucidated adequately. Nevertheless, the following field relations were observed that indicate emplacement as a fluid magma: (1) The porphyritic phase commonly shows a marked decrease in grain size along contacts with wallrock that suggests a chilled zone. (2) Contacts with wallrock are generally sharp but locally appear gradational, partly because of similarity in grain size on both sides of the contact that may have resulted from chilling of the intrusive rock and concomitant coarse recrystallization of wallrock; similarity of 
appearance is enhanced by a similar color index in both rocks. (3) Dikes of the porphyritic phase cut rocks of the dioritic phase and contain inclusions resembling the latter, although gradation between rocks of the two phases was also noted locally. (4) Protoclastic zones near borders were noted locally. Recognizing that a substantial amount of assimilation and hybridization of wallrock may have accompanied emplacement of the pluton, we believe that the data nevertheless weigh heavily in favor of the pluton's emplacement as fluid magma rather than its formation in place through metasomatic processes alone.

A potassium-argon biotite age determination of $88.8 \pm 2.8$ m.y. (table 3) was made on a sample collected in the Okanogan quadrangle from the northeast side of the Conconully-Omak highway, $1.5 \mathrm{~km}(1$ mi) southeast of the point where the highway crosses the mutual boundary of the Conconully and Okanogan quadrangles ( $\mathrm{SW}^{1 / 4} \mathrm{sec}$. 32 , T. 35 N., R. 26 E.). Hornblende was not dated because of extensive alteration to bowlingite(?), and the biotite age must therefore be considered a minimum age for the pluton.

\section{QUARTZ MONZONITE WEST OF SALMON CREEK}

A small part of Menzer's (1965) Loup Loup Granodiorite is exposed in the southwest corner of the quadrangle. It is homogeneous, coarse, even-grained, massive quartz monzonite but grades to porphyritic quartz monzonite and granodiorite in the Tiffany Mountain quadrangle to the northwest. Contacts with adjacent rocks are locally sharp but commonly are gradational through a hybrid zone rich in schlieren; local zones of lit-par-lit injection are also fairly common. In a typical specimen the texture is xenomorphic-granular, and the composition is quartz monzonite, consisting of microperthitic microcline, weakly zoned oligoclase, and quartz, with biotite the chief dark mineral; the color index is 4 .

Menzer (1970) gives the following age data for a granodiorite sample he collected 8 to $10 \mathrm{~km}$ ( 5 to $6 \mathrm{mi}$ ) west of the Conconully quadrangle, presumably from this pluton, on the basis of recent unpublished mapping by us and our interpretation of a small-scale diagram of Menzer's (1970, fig. 1):

\begin{tabular}{|c|c|c|c|}
\hline Method & & Mineral & Age (m.y.) \\
\hline rubidium-strontium & - & apatite & $81.1 \pm 0.8$ \\
\hline rubidium-strontium & & biotite & $81.1 \pm 0.8$ \\
\hline fission-track & & apatite & $89 \pm 9$ \\
\hline fission-track & & sphene & $84 \pm 8$ \\
\hline lead-alpha & & zircon & $90 \pm 20$ \\
\hline
\end{tabular}

Agreement of the data is fairly good and yields an average of 85 m.y. Apparently because of the precision of the rubidium-strontium de- 
termination, Menzer refers to the pluton's intrusion as "the $81 \mathrm{~m} . \mathrm{y}$. event."

Potassium-argon age determinations on both biotite and hornblende (table 3 ) were made on a sample collected from a roadcut, a little more than a kilometre $(0.6 \mathrm{mi})$ west of Conconully Reservoir, at a point where the road crosses the South Fork of Salmon Creek (Tiffany Mountain quadrangle). The rock there is coarse-grained porphyritic granodiorite and is continuous with the rock exposed west of Salmon Creek in the Conconully quadrangle. Hornblende and biotite were dated at $72.8 \pm 4.6$ and $62.5 \pm 2.2$ m.y., respectively, these results differing markedly from those reported by Menzer (1970). This difference, together with the discordance shown by the potassium-argon mineral ages, suggest that a younger thermal event, centered east of the pluton, may have reduced the apparent mineral ages in the eastern part of the pluton.

\section{ROCKS OF THE OKANOGAN GNEISS DOME}

Plutonic rocks of the Okanogan gneiss dome comprise two mapped units of gneiss-the Tonasket Gneiss, composed of layered cataclastic gneiss, and a second unit of cataclastic granitoid gneiss-that occupy an area of about $10 \mathrm{~km}^{2}\left(4 \mathrm{mi}^{2}\right)$ in the southeastern part of the quadrangle. These rocks form a small segment of what Waters and Krauskopf (1941) interpreted as the protoclastic western border of the Colville batholith. Snook (1965) restudied part of the terrane described by Waters and Krauskopf, including that part lying within the Conconully quadrangle, and reinterpreted the rocks as medium- to highgrade paragneiss that was subsequently modified by extensive cataclasis. It is our view that much of the terrane formerly regarded as the Colville batholith is best interpreted as a gneiss dome (U.S. Geological Survey, 1970; Fox and Rinehart, 1971; Fox and others, 1973).

The Tonasket Gneiss, a name originally used by Snook (1965) and later redefined by Fox, Rinehart, Engels, and Stern (1974), applies to a unit of layered cataclastic gneiss composed of individual layers that range in thickness from less than a centimetre to a few metres and in composition from gabbro to alaskite; its overall bulk composition is probably quartz diorite. The layers typically pinch out or grade into other layers within short lateral distances. Thin mylonite zones a few metres to a few tens of metres apart, parallel or subparallel to foliation, occur sporadically throughout the unit. Lineation, consistently in the plane of foliation, is nearly ubiquitous and is defined by the alinement of hornblende prisms, linear trains of hornblende or biotite, and streaking and crystallographic parallelism of quartz. Minor folds are sporadically distributed, their axes generally parallel or subparallel to the lineation. 
The unit of cataclastic granitoid gneiss is similar to the layered cataclastic gneiss, with which it is in sharp contact, but it is more homogeneous and not layered, though generally well foliated.

Potassium-argon and fission-track age determinations by Joan C. Engels suggest emplacement in Late Cretaceous time (U.S. Geological Survey, 1970, p. A123).

\section{SANDSTONE AND CONGLOMERATE}

Sandstone and conglomerate form discontinuous structureless outcrops at the western edge of the Carter Mountain volcanic terrane, where their thickness is generally $15 \mathrm{~m}(50 \mathrm{ft})$ or less but locally as much as $45 \mathrm{~m}(150 \mathrm{ft})$. The sedimentary rocks are unconformable on metamorphic rocks and grade fairly abruptly into overlying tuff. The conglomerate is well lithified and generally has a high clast to matrix ratio, the clasts commonly consisting of rounded metamorphic rocks, locally as much as $60 \mathrm{~cm}(2 \mathrm{ft})$ across but more typically 2 to $5 \mathrm{~cm}(1-2$ in.). A small patch of conglomerate with abundant granitic clasts is exposed on Bald Butte at the western edge of the quadrangle; $1.5 \mathrm{~km}$ (1 mi) farther northwest, in the Tiffany Mountain quadrangle, similar conglomerate lies at the base of volcanic rocks continuous with those at Twin Peaks in the northwest corner of the Conconully quadrangle. The sedimentary rocks are considered to be of Eocene age because of their gradational relation with the overlying radiometrically dated volcanic rocks of Eocene age.

\section{VOLGANIC ROCKS}

\section{DACITE OF CARTER MOUNTAIN}

A volcanic sequence consisting of four mapped units, possibly 1,200 to $1,500 \mathrm{~m}(4,000$ to $5,000 \mathrm{ft})$ thick, occupies about $40 \mathrm{~km}^{2}\left(16 \mathrm{mi}^{2}\right)$ in the east-central part of the quadrangle. The sequence is chiefly lava flows and pyroclastic rocks that are dominantly dacite but range from andesite to quartz latite.

\section{CRYSTAL-LITHIC AND CRYSTAL TUFF}

The crystal-lithic and crystal tuff is typically light gray with local variation to buff, tan, pale red, lavender, and pale green. Crystals, 1 to $2 \mathrm{~mm}$ in maximum dimension, compose 35 to 50 percent of the rock; most are oligoclase with lesser amounts of sanidine, quartz, and local hornblende. Secondary clay and chlorite are common. Subangular autoliths and xenoliths are locally abundant. Thin beds or lenses of tuffaceous sediment are present in places, and near the base of the tuff, close to its western margin, several lenticular beds of conglomerate are interlayered with the tuff. The rock is typically massive, 
although bedding or layering is locally present. The maximum thickness, on the west flank of Carter Mountain, is about $600 \mathrm{~m}(2,000 \mathrm{ft})$.

\section{QUARTZ-POOR FLOW}

The quartz-poor flow is dacite in composition, chiefly medium-gray but commonly shows variation to shades of red and purple. The rock is typically porphyritic and contains conspicuous light-gray 1- to 2-mm, equant or lath-shaped plagioclase phenocrysts in a darker matrix. The phenocrysts, which make up about 40 percent of the rock, also include sparse hornblende, biotite, and augite. The rock is typically massive but locally shows flow layering. No intercalated tuff beds were found within the unit. The quartz-poor flow forms a virtual lentil within the unit of crystal-lithic and crystal tuff, except for a linear distance of about $1.5 \mathrm{~km}(1 \mathrm{mi})$ along the flow's eastern margin where it is overlain by quartz-bearing flows. The quartz-poor flow is thickest-about $450 \mathrm{~m}(1,500 \mathrm{ft})$-in its central part, pinching out within $1.5 \mathrm{~km}(1 \mathrm{mi})$ to the northwest and to the southeast. Brecciation and shattering of rocks in the south-central part of section 16 suggest that a vent may be located nearby.

\section{QUARTZ-BEARING FLOWS}

The quartz-bearing flows consist chiefly of medium-gray dacite but show color variation from light to dark gray, locally modified by somewhat subtler shades of pink and lavender than shades of these colors in the quartz-poor flow. The rocks are typically porphyritic and contain conspicuous light-gray 1- to 3-mm, equant or lath-shaped plagioclase phenocrysts in a darker matrix. The phenocrysts, which make up about 40 percent of the rock, also include sparse quartz, hornblende, biotite, and augite. The presence of quartz phenocrysts served as the chief criterion in distinguishing this unit from the quartz-poor flow. The rocks are typically massive but locally show flow layering, and columnar joints are conspicuous near the crest of Carter Mountain. Maximum total thickness of the quartz-bearing flows, including the numerous thin, discontinuous tuff beds interbedded at scattered localities, probably is about 150 to $300 \mathrm{~m}$ (500 to $1,000 \mathrm{ft}$ ). The unit is mainly conformable above the unit of crystallithic and crystal tuff, but it locally fills channels in the tuff, and it directly overlies the quartz-poor flow south of Carter Mountain.

A potassium-argon hornblende age of $45.1 \pm 2$ m.y., about middle Eocene, was determined by Joan C. Engels from a sample collected about $1 \frac{1}{2} \mathrm{~km}(1 \mathrm{mi})$ east of the benchmark on the summit of Carter Mountain. The pertinent analytical data are: sample number $\mathrm{C}-550$; percent $\mathrm{K}_{2} \mathrm{O}=0.7955 ;{ }^{40} \mathrm{Ar}$ (radiogenic) in moles/gram $=5.358 \times 10^{-11}$, percent radiogenic $\mathrm{Ar}=58.8$. 
INTRUSIVE ROCKS

Hypabyssal intrusive bodies, mostly dikes, are widely distributed throughout the quadrangle but are abundant only in the extreme northern end of the Carter Mountain volcanic terrane. The rocks are dacite, petrographically similar to flows in the Carter Mountain area and probably comagmatic with them. Chilled contacts, xenoliths, and autoliths are common. The large east-trending dikes at the northern end of the volcanic belt, west of Aeneas Lake, are shown as diagrammatic representations in a terrane complexly intruded by varied fluidal rocks and breccias and are probably the eroded remnants of several major vents.

\section{VOLCANIC ROCKS, UNDIVIDED}

This undivided map unit includes small isolated outcrops of flows, pyroclastic rocks, hypabyssal intrusive rocks, and some interlayered sandstone and conglomerate. The volcanic rocks range in composition from andesite to quartz latite but probably average near rhyodacite. They are similar to and are probably coeval with the volcanic rocks of Carter Mountain, hence, together with the interlayered sedimentary rocks, are inferred to be Eocene in age.

\section{ANDESITE OF TWIN PEAKS}

An almost structureless sequence of medium- to dark-gray volcanic rocks, at least $450 \mathrm{~m}(1,500 \mathrm{ft})$ thick, ranging in composition from dacite to andesite, occupies about $5 \mathrm{~km}^{2}\left(2 \mathrm{mi}^{2}\right)$ in the northwestern part of the quadrangle and covers an additional few tens of square kilometres to the northwest. The rocks are porphyritic andesite consisting of 20 to 30 percent oligoclase phenocrysts 1 to $2 \mathrm{~mm}$ long, minor quartz phenocrysts, and interstitial potassium feldspar in a cryptocrystalline matrix. Flow breccias predominate and are characterized by abundant $1-$ to $3-\mathrm{cm}$ subangular to subrounded autoliths that are conspicuous on weathered surfaces; massive flows are sporadically interlayered with the breccias but are subordinate in amount. Alteration is extensive; hornblende, biotite, and local augite occur as relict cores surrounded by calcite, epidote, and chlorite, bordered by magnetite rims that preserve original crystal outlines. Although this suite does not appear to include rocks as felsic as some in the Carter Mountain suite, considering the overall compositional similarity as well as similarities in degree of preservation, deformation, and alteration, the two terranes appear to be virtually equivalent in age.

\section{PETROCHEMISTRY}

Seven specimens of the volcanic rocks were analyzed chemically 
and spectrographically; results are given on table 4 . The seven were selected from a suite of 31 specimens whose silica content had been

TABLE 4.-Chemical and spectrographic analyses and CIPW norms of volcanic rocks; nomenclature after Rittman (1952)

[Analysts for chemical analyses: P. Elmore, L. Artis, H. Smith, J. Glenn, and J. Kelsey. Analyses by the rapid method of Shapiro and Brannock (1956), supplemented by atomic absorption. Analyst for spectrographic analyses: R. E. Mays. Results are identified with numerical brackets whose boundaries are $1.2,0.83,0.56,0.38,0.26,0.18$, 0.12 but are reported arbitrarily as midpoints of these brackets: $1 ., 0.7,0.5,0.3,0.2,0.15,0.0$. The precision of a reported value is approximately plus or minus one bracket at 68 percent, or two brackets at 95 percent confidence. Looked for but not found: Ag, As, Au, B, Be, Bi, Cd, Ce, Ge, Hf, In, La, Li, Mo, Nb, Pd, Pt, Re, Sb, Sn, Ta, Te, Th, Tl, $\mathrm{U}, \mathrm{W}, \mathrm{Zn}]$

\begin{tabular}{|c|c|c|c|c|c|c|c|c|}
\hline \multicolumn{4}{|c|}{ Twin Peaks area } & \multicolumn{5}{|c|}{ Carter Mountain area } \\
\hline & & $\begin{array}{c}\mathrm{C}-5 \\
\text { Dacite }\end{array}$ & $\begin{array}{l}\text { C-51-A } \\
\text { Trachy- } \\
\text { andesite }\end{array}$ & $\begin{array}{c}\text { C-62-B } \\
\text { Quartz } \\
\text { latite }\end{array}$ & $\begin{array}{l}\text { C-550 } \\
\text { Dacite }\end{array}$ & $\begin{array}{c}\text { C-112-A } \\
\text { Rhyo- } \\
\text { dacite }\end{array}$ & $\begin{array}{c}\text { C-78-C } \\
\text { Rhyo- } \\
\text { dacite }\end{array}$ & $\begin{array}{l}\text { C-112-B } \\
\text { Trachy- } \\
\text { andesite }\end{array}$ \\
\hline \multicolumn{9}{|c|}{ Chemical analyses } \\
\hline $\begin{array}{l}\mathrm{SiO}_{2} \\
\mathrm{Al}_{2} \mathrm{O}_{3} \\
\mathrm{Fe}_{2} \mathrm{O}_{3} \\
\mathrm{FeO} \\
\mathrm{MgO} \\
\mathrm{CaO} \\
\mathrm{Na}_{2} \mathrm{O} \\
\mathrm{K}_{2} \mathrm{O} \\
\mathrm{H}_{2} \mathrm{O} \\
\mathrm{H}_{2} \mathrm{O}^{+} \\
\mathrm{TiO}_{2} \\
\mathrm{P}_{2} \mathrm{O}_{5} \\
\mathrm{MnO}^{\mathrm{CO}_{2}}\end{array}$ & 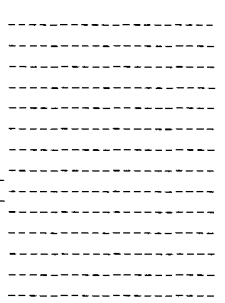 & $\begin{array}{l}61.0 \\
16.8 \\
2.4 \\
1.1 \\
1.7 \\
4.6 \\
6.0 \\
.93 \\
.20 \\
1.8 \\
.62 \\
.26 \\
.05 \\
2.1\end{array}$ & $\begin{array}{c}56.6 \\
17.3 \\
3.5 \\
2.6 \\
3.5 \\
4.8 \\
4.0 \\
1.8 \\
.66 \\
2.8 \\
.86 \\
.42 \\
.08 \\
.42\end{array}$ & $\begin{array}{l}67.8 \\
16.8 \\
1.0 \\
.72 \\
.58 \\
2.4 \\
3.7 \\
4.1 \\
.86 \\
1.3 \\
.29 \\
.10 \\
.00 \\
<.05\end{array}$ & $\begin{array}{c}64.1 \\
15.8 \\
3.2 \\
.36 \\
2.0 \\
4.5 \\
3.7 \\
1.7 \\
1.2 \\
2.4 \\
.55 \\
.23 \\
.07 \\
<.05\end{array}$ & $\begin{array}{c}61.0 \\
17.0 \\
4.0 \\
1.1 \\
2.5 \\
3.7 \\
4.2 \\
2.9 \\
.55 \\
1.8 \\
.75 \\
.36 \\
.05 \\
<.05\end{array}$ & $\begin{array}{c}60.6 \\
16.3 \\
3.0 \\
2.0 \\
2.4 \\
5.0 \\
3.5 \\
2.8 \\
.36 \\
1.5 \\
.79 \\
.42 \\
.06 \\
.86\end{array}$ & $\begin{array}{c}53.7 \\
16.8 \\
2.6 \\
3.6 \\
3.8 \\
7.2 \\
2.9 \\
1.3 \\
.63 \\
3.2 \\
.07 \\
.51 \\
.05 \\
2.8\end{array}$ \\
\hline & Total & 99.56 & 99.34 & 99.65 & 99.81 & 99.91 & 99.59 & 99.16 \\
\hline
\end{tabular}

CIPW norms (weight percent)

\begin{tabular}{|c|c|c|c|c|c|c|c|}
\hline 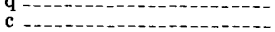 & $\begin{array}{r}12.5 \\
.0\end{array}$ & $\begin{array}{r}12.4 \\
1.1\end{array}$ & $\begin{array}{r}25.0 \\
2.2\end{array}$ & $\begin{array}{r}25.1 \\
.3\end{array}$ & $\begin{array}{r}15.2 \\
1.1\end{array}$ & $\begin{array}{r}17.3 \\
.0\end{array}$ & $\begin{array}{r}11.8 \\
.0\end{array}$ \\
\hline or & 5.8 & 11.1 & 24.9 & 10.4 & 17.6 & 17.1 & 8.3 \\
\hline $\mathrm{ab}$ & 53.2 & 35.5 & 32.1 & 32.5 & 36.4 & 30.5 & 26.5 \\
\hline an & 16.9 & 22.1 & 11.5 & 21.6 & 16.4 & 21.2 & 31.3 \\
\hline wo & 2.2 & .0 & .0 & .0 & .0 & .7 & 1.5 \\
\hline en & 4.4 & 9.1 & 1.5 & 5.2 & 6.4 & 6.2 & 10.2 \\
\hline fs & .0 & .6 & .0 & .0 & .0 & .0 & 4.8 \\
\hline $\mathrm{mt}$ & 2.0 & 5.3 & 1.5 & .0 & 1.6 & 4.5 & 4.1 \\
\hline hm & 1.1 & .0 & .0 & 3.3 & 3.0 & .0 & .0 \\
\hline il - & 1.2 & 1.7 & 6 & 1.0 & 1.5 & 1.6 & .1 \\
\hline ru & .0 & .0 & .0 & .1 & .0 & .0 & .0 \\
\hline ap & .7 & 1.0 & .2 & .6 & .9 & 1.0 & 1.3 \\
\hline Total & 100.0 & 99.9 & 100.0 & 100.1 & 100.1 & 100.1 & 99.9 \\
\hline
\end{tabular}

Spectrographic analyses for minor elements, in ppm

\begin{tabular}{|c|c|c|c|c|c|c|c|}
\hline $\mathrm{Ba}$ & $-1-1-300$ & 1,000 & 1,500 & 1,500 & 2,000 & 2,000 & 1,000 \\
\hline Co & 0 & 20 & 0 & 10 & 10 & 10 & 20 \\
\hline $\mathrm{Cr}$ & - & 20 & 0 & 30 & 10 & 30 & 150 \\
\hline $\mathrm{Cu}$ & 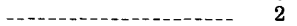 & 30 & 1 & 10 & 10 & 10 & 30 \\
\hline $\mathrm{Ga}$ & 15 & 20 & 20 & 20 & 20 & 20 & 20 \\
\hline $\mathrm{Ni}$ & 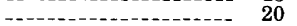 & 20 & 0 & 20 & 7 & 20 & 70 \\
\hline $\mathrm{Pb}$ & 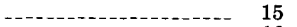 & 15 & 15 & 15 & 15 & 15 & 15 \\
\hline Sc & 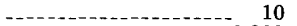 & 15 & 0 & 7 & 10 & 10 & 20 \\
\hline $\mathrm{Sr}$ & 2,000 & 2,000 & 1,500 & 2,000 & 2,000 & 2,000 & 1,500 \\
\hline$V_{-}$ & 100 & 150 & 30 & 100 & 150 & 150 & 200 \\
\hline Y & - & 20 & 0 & 15 & 15 & 15 & 20 \\
\hline $\mathbf{Y b}$ & - & 2 & 1 & 1 & 2 & 2 & 2 \\
\hline $\mathrm{Zr}$ & 100 & 150 & 150 & 150 & 200 & 200 & 150 \\
\hline
\end{tabular}


previously estimated, using procedures described by Huber and Rinehart (1966). The analyzed specimens span the measured range in silica content of the entire volcanic suite. A silica refractive index curve for the suite is plotted in figure 10. The specimens represent differing modes of origin as well as compositional types. Specimens $\mathrm{C}-51 \mathrm{~A}, \mathrm{C}-550, \mathrm{C}-112-\mathrm{A}$, and $\mathrm{C}-78-\mathrm{C}$ represent flows, $\mathrm{C}-5$ is a flow breccia, $\mathrm{C}-62-\mathrm{B}$ is a crystal tuff, and $\mathrm{C}-112-\mathrm{B}$ is a probable feeder dike. The only rock whose analysis seems somewhat abnormal is $\mathrm{C}-5$, a flow breccia from the Twin Peaks area. For its silica content, it is unusually low in $\mathrm{K}_{2} 0$, somewhat low in total $\mathrm{Fe}$, and high in $\mathrm{Na}_{2} \mathrm{O}$. Thin section examination revealed nothing unusual although, like most of the other volcanic rocks, more than half of the rock is cryptocrystalline matrix.

Sixty percent or more of each specimen is composed of microscopi-

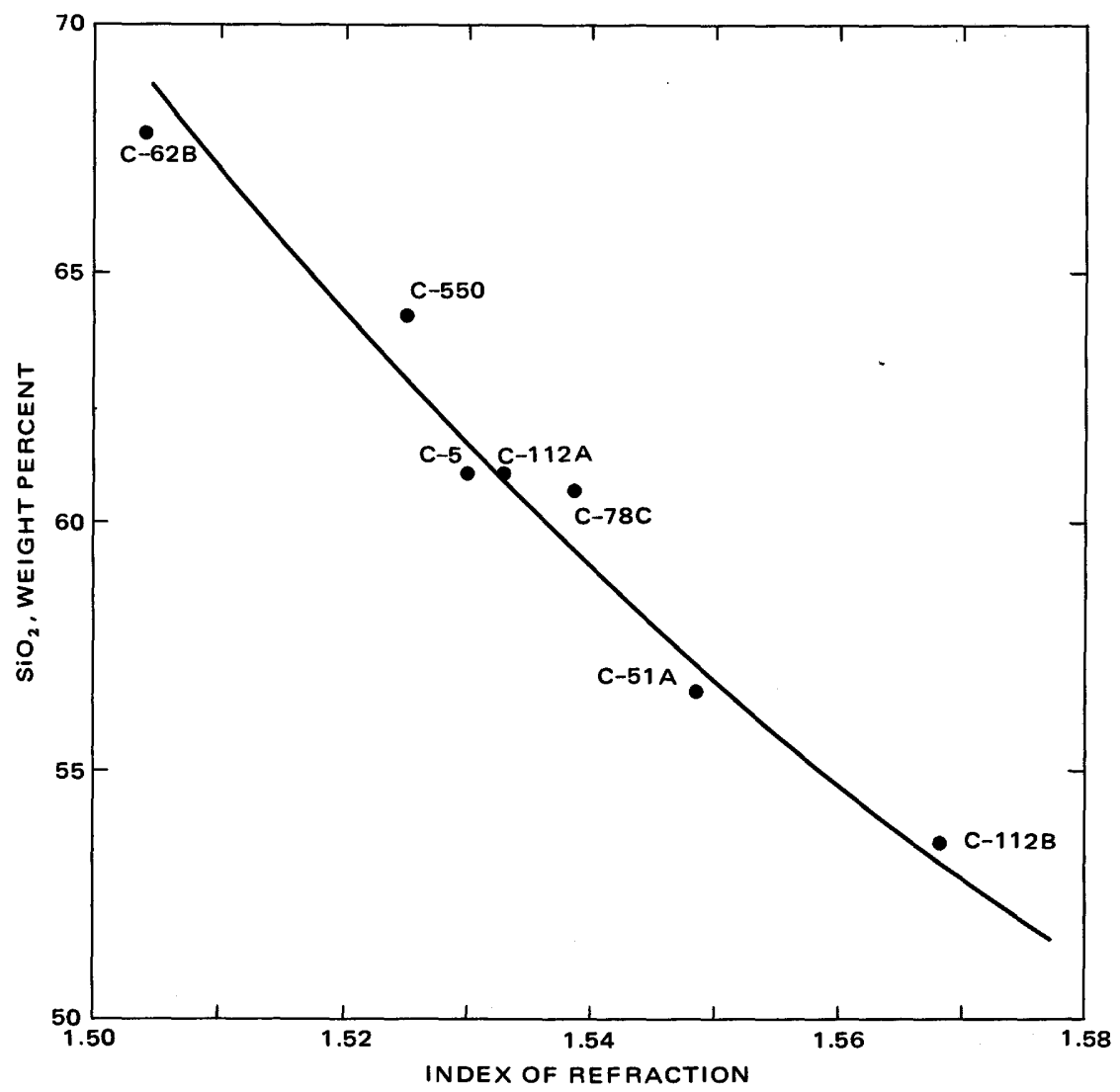

Figure 10.-Silica versus refractive index curve for Cenozoic volcanic rocks in the Conconully quadrangle. 
cally unresolvable matrix that appears to be largely a mixture of alteration products and devitrified glass. Plagioclase is oligoclase or andesine with the anorthite content showing little correlation with the silica content of the rock. Quartz is sparse in all samples. Potassium feldspar (sanidine) was recognized only in specimen C-62-B. Hornblende is the commonest dark mineral and occurs in all but specimen C-5. C-5 and C-62-B contain the only biotite found in all the samples. The biotite occurs as ragged relicts embedded in fuzzy patches of alteration products that include epidote, calcite, clay, zeolites(?), and opaque minerals. The common accessory minerals in the suite are apatite, magnetite, allanite, and sphene; a few augite crystals were found in specimen C-550.

A silica variation diagram (fig. 11) shows major oxide trends in the suite and their relation to average comparable rocks of Nockolds (1954). The local suite appears to differ most from Nockolds' average rocks by its lower content of lime and of total iron. The alkali-lime index (fig. 12) of Peacock (1931) indicates that the suite is virtually on the borderline between the calc-alkalic and alkalic-calcic igneous series. It is notable that the unusual $\mathrm{K}_{2} \mathrm{O}$ to $\mathrm{Na}_{2} \mathrm{O}$ ratio of specimen C-5 has no effect on this index because the sum rather than the ratio is important in the determination.

\section{SURFICIAL DEPOSITS}

Surficial deposits in the quadrangle consist of glacial drift, alluvial fan and flood plain deposits, and aprons and cones of talus. In addition, a landslide has been delineated along the bluff overlooking Wagonroad Coulee from the west. Glacial drift forms a blanket of silt, sand, and gravel that is discontinuous and thin on the uplands but widespread and thick in the valleys. Kames and kettles are well developed at Graveyard Flat east of Conconully Reservoir and in Wagonroad Coulee; two eskers can be seen south of Scotch Creek Grange Hall and east of Hess Lake.

The alluvial deposits consist of coarse, poorly sorted gravel in the fans, and bedded deposits of sand and gravel in flood plains of the major drainage channels. Talus deposits are composed of coarse, unconsolidated, angular debris.

A landslide, first noted by Bennett $(1944$, p. 22), is located west of Booher Lake, forming part of the west wall of Wagonroad Coulee. The landslide is a series of large blocks, which, after becoming detached from the adjacent bedrock, have evidently crept en masse outward and downward to their present position. Rock within the landslide blocks is fractured but still coherent. The slide shows the greatest dislocation-several hundred metres downward and outward from its initial position, presumed to have been at the coulee rim-at the 
SURFICIAL DEPOSITS
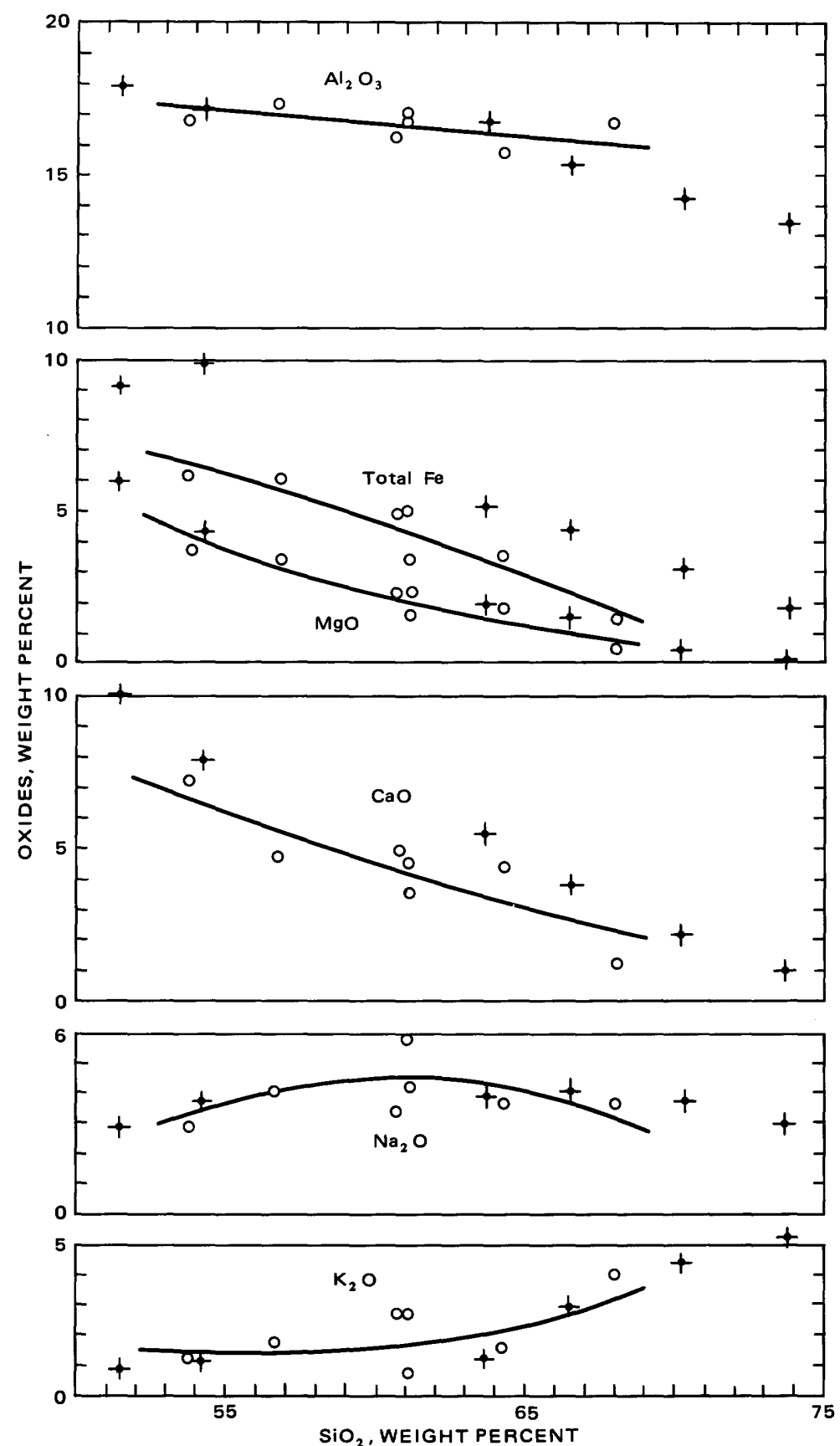

FigURe 11.-Silica variation diagram from the Cenozoic volcanic rocks. For comparison, the following average rocks of Nockolds (1954) are plotted as crosses (left to right): central basalt, andesite, dacite, rhyodacite, dellenite, rhyolite. 

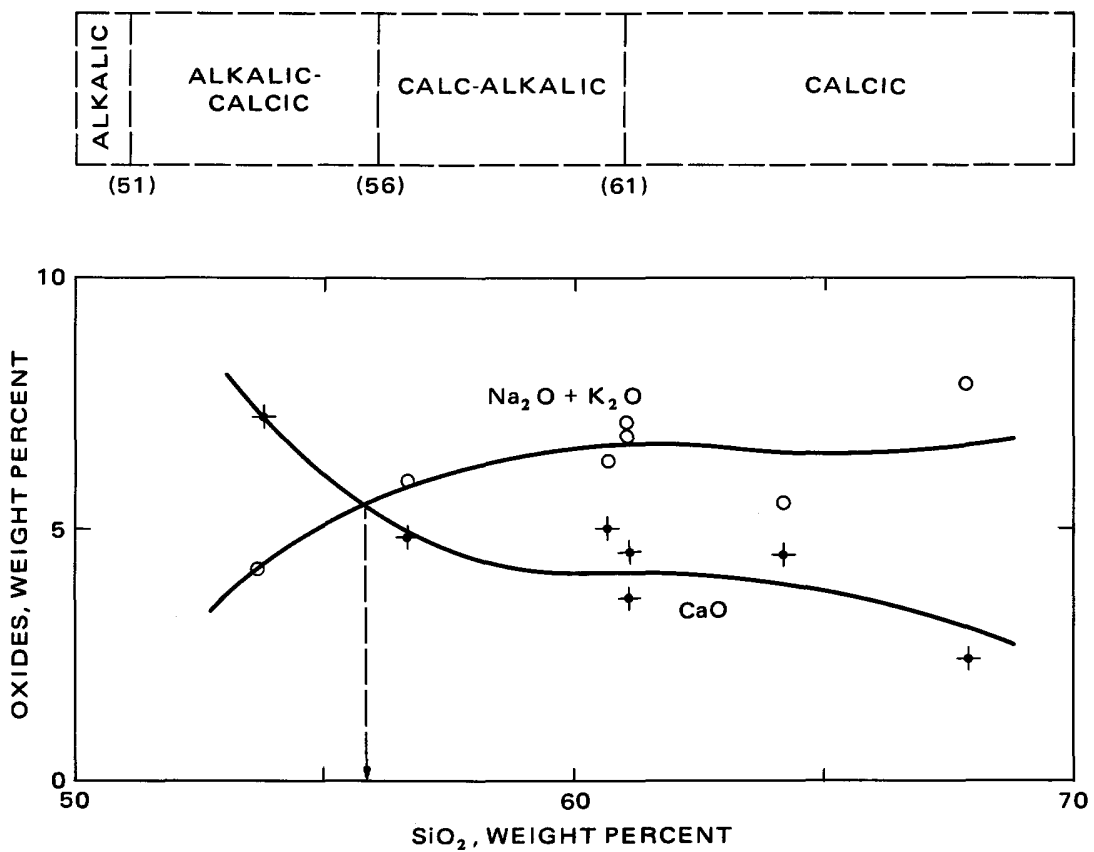

FIGURE 12.-Silica variation diagram showing alkali-lime index (Peacock, 1931) of the Cenozoic volcanic suite in the Conconully quadrangle.

southern extremity where it now forms a prominent bench midway up the coulee wall.

The surface of the bench within the landslide slopes upward to the northwest. At the northwestern extremity, the slide block has evidently moved several metres outward, opening crevasses along the plane of separation that are now partly filled with a jumble of frostriven blocks of the adjacent bedrock. At that locality the block shows no obvious downward offset and-perched precariously more than $300 \mathrm{~m}(1,000 \mathrm{ft})$ above the coulee floor-still forms the coulee rim.

Bennett $(1944$, p. 21,22$)$ noted the presence of smaller slide blocks, which we have not mapped, along the coulee wall south-southeast of the locality described above.

\section{GEOLOGIC STRUGTURE}

The geologic structure in the quadrangle is discussed with respect to four main elements: (1) folds, (2) faults, (3) foliation in the metamorphic rocks, and (4) lineation and gneissosity in rocks of the Okanogan gneiss dome.

The Anarchist Group in the northern part of the quadrangle is folded into a series of moderately overturned folds (sections $A-A^{\prime}$ and 
$\left.B-B^{\prime}\right)$ with axial planes dipping steeply west. The axial planes of these folds, when followed to the southeast, rotate through vertical to steep eastward dips as the strike of the fold axes shifts from north to northwest (section $C-C^{\prime}$ ).

The syncline cored by the Kobau(?) Formation east of Horse Springs Coulee shows a similar but less marked shift in trend when followed from north to south-from an upright fold with northstriking axial plane to an overturned fold with moderately eastdipping axial plane (sections $A-A^{\prime}, B-B^{\prime}, C-C^{\prime}$ ).

No major folds were mapped in the metamorphic complex of Conconully in the western and central parts of the quadrangle because of the absence of marker beds and the difficulty of determining bedding-top direction in these strata. Inspection of bedding and foliation attitudes suggests that major folds are present, analogous to those found to the north in the Anarchist, moderately overturned, and striking chiefly northward.

The northwest- to north-trending structures of the Anarchist Group in the northern part of the quadrangle and in the complex of Conconully, to the south, are interrupted southwest of Horse Springs Coulee by an intervening sharply divergent, east-trending structural belt, defined by bedding and foliation in both of the above units, and by a linear body of metadiorite and meta-quartz diorite. This belt is probably attributable to refolding after the earlier north- to northwesttrending structures were formed. Other structures with divergent trends include the northeast-trending minor folds of the Schallow Mountain area northeast of Conconully, and the broad eastnortheast-trending anticline in the Cave Mountain Formation west of Horseshoe Lake in the south-central part of the quadrangle.

The Cave Mountain Formation, although strongly folded, is readily separable into several distinctive units permitting a relatively unambiguous solution of their structure. The interpretation presented here (sections $D-D^{\prime}, E-E^{\prime}, F-F^{\prime}$ ) is based on the premise that the basal dark-gray metalimestone member does not correlate with the dark-gray slate and metalimestone member here inferred to be higher in the section. Admittedly, both units contain much very similar dark-gray to sooty-black metalimestone. Both units are directly associated with metasiltstone or quartzite, the basal dark-gray metalimestone member being overlain by a mapped metasiltstone layer, and the slate and metalimestone layer containing an unmapped unit of metasiltstone at its base. However, the basal dark-gray metalimestone member does not contain the intercalated dark-gray slate so characteristic of the upper dark-gray slate and metalimestone member throughout most of its extent. Furthermore, indications of bedding-top directions in the mapped metasiltstone show that the 
section is right-side-up in the homoclinal terrane at the type locality of the formation, and in exposures continuous to the east.

The Cave Mountain Formation is folded into a series of overturned folds whose axial planes dip generally west,and whose axial traces when followed from north to south, show a progressive shift in strike from north-northeast to north, then northwest. Thus the axial planes of these folds very roughly parallel and dip away from the margin of the Okanogan gneiss dome east of Wagonroad Coulee.

Minor folds (fig. 13) ranging in size from minute crenulations to folds with amplitudes and wavelengths of several metres are widespread in the metamorphic rocks. Fold axes typically plunge gently, but no general regional trend was recognized. Locally, axial trends make a fairly consistent pattern as, for example, at Funk Mountain 3 to $5 \mathrm{~km}$ ( 2 to $3 \mathrm{mi}$ ) north of Conconully where axial trends are northwest. In Schallow Mountain, adjacent to the east, northeast

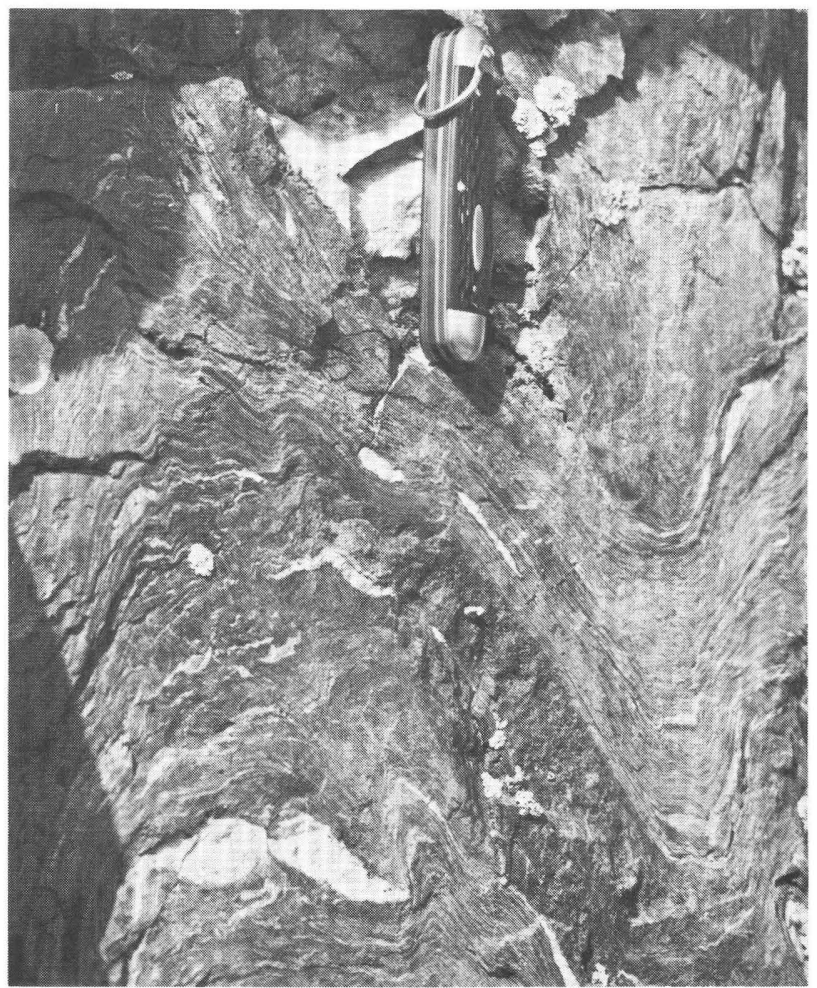

Figure 13.-Minor folds typical of metasiltstone in the metamorphic complex of Conconully; Funk MountainSchallow Mountain area. Folds show chevron style common in this region. 
trends predominate although northwest trends are also present. In the folded carbonate sequence of the Cave Mountain Formation, minor fold axes are not typically parallel to major fold axes although local parallelism can be found. At most outcrops where axes with more than one trend are shown, refolding can generally be demonstrated, indicating a complex deformational history in the region.

Faults, as shown on the map, are notably most numerous in the same areas as those in which major folds are shown, and for doubtless the same reason-stratigraphically distinct units are present that make offsets along faults easy to recognize. Faults also cut and displace nonfolded volcanic rocks of Cenozoic age in the east central part of the quadrangle. Most faults within the quadrangle are normal faults, but several low to moderately west-dipping thrusts cut the limbs of overturned folds in the Cave Mountain Formation west of Wagonroad Coulee.

In the Cave Mountain Formation, the contact between the

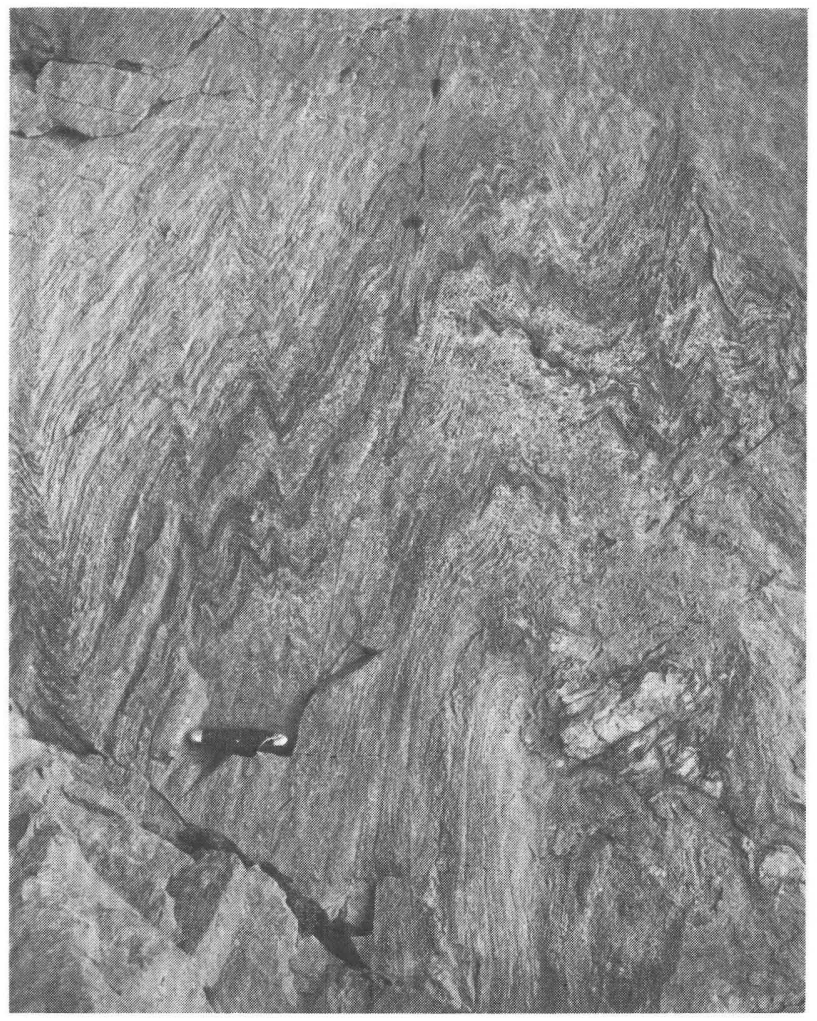

Figure 13-Continued 
metadolomite and metalimestone member and the underlying Anarchist Group, exposed in windows west of Wagonroad Coulee, was described first, and in some detail, by Waters and Krauskopf (1941, p. 1365) who interpreted it as an unconformity. Later, Misch (1951) interpreted this same contact as a thrust fault. His interpretation may have been based partly on his supposition (Misch, 1949a, p. 687; 1949b), later refuted (Misch, 1966, p. 118), that the dolomites were Paleozoic (probably Devonian) rather than Late Triassic and thus older than the underlying Anarchist Group of Permian age. Our observations, however, as noted in the lithologic description of the metadolomite and metalimestone member, are similar to those reported by Waters and Krauskopf, and support the view that this is a depositional contact, not a thrust fault.

The Cayuse Mountain thrust fault mapped in the Loomis quadrangle (Rinehart and Fox, 1972, p. 71) to the north evidently continues into the Conconully quadrangle beneath the alluvium of Horse Springs Coulee. A fault at that location seems necessary to explain the juxtaposition of eastward-dipping but probably overturned Anarchist strata on the west against rocks of the Kobau(?) Formation, which form the core of an overturned syncline, on the east (pl. 1, sections $\left.A-A^{\prime}, B-B^{\prime}, C-C^{\prime}\right)$.

A fault of unknown magnitude may be present between the Anarchist Group and the complex of Conconully, possibly following the contact(s) of the elongate gneissic pluton of meta-quartz diorite southeast of Lemanasky Lake. As previously noted, the pluton is one element in an east-trending structural belt that diverges from a more general north-northwest regional grain. The coincidence of these divergent structures with the presence of a pluton that occupies the stratigraphic interval from which the Cave Mountain Formation (expected in the normal stratigraphic succession) is missing invites such speculation. Although there is no field evidence of an unconformity, there is also no field evidence of major faulting, hence a solution to the problem must be sought using some other approach. If this apparent stratigraphic gap indeed represents a fault, it could be a continuation of the Cayuse Mountain thrust; if so, the entire Lemanasky Mountain area would be allochthonous. Since bedding on both sides of the hypothetical fault is roughly parallel, and field evidence of a fault is lacking, we believe the simpler solution is to assume that the metamorphic complex of Conconully overlies the Anarchist Group unconformably along this contact, but we readily acknowledge that this solution is, at best, tentative.

In the southwest corner of the quadrangle, a steeply dipping, north-northwest-trending fault forms the contact between biotite schist (contining minor interlayers of marble and calc-hornfels) of the 
Conconully complex and metadiorite. The fault zone has been eroded to form a linear, V-shaped segment of the valley of Salmon Creek. Diagonal-slip slickensides plunging to the south-southeast are exposed in subsidiary shears adjacent to the inferred axis of the fault zone. However, neither the sense of displacement nor the amount of offset is known.

Foliation in the metamorphic rocks is typically well developed and is mostly parallel to bedding. Attitudes near plutons are generally subparallel to the intrusive contacts, and in the Funk MountainSchallow Mountain area northeast of Conconully the attitudes define the flanks of a dome.

Lineation is a conspicuous feature of gneissic rocks of the Okanogan gneiss dome. Elements of the lineation include parallel orientation of elongate clusters of quartz grains and trains of mica revealed on broken surfaces of the rock by fluting and streaking. The gneisses are also foliated, and most are layered. Fold axes are generally parallel to the lineation. It is significant that the general outline of the salient of the gneiss dome that projects into the quadrangle is parallel to a reentrant in the metamorphic terrane to the west, and also parallel to traces of planar structures within the gneiss. This suggests that Wagonroad Coulee conceals part of the intrusive border of the gneiss dome in this area, rather than expressing the trace of a steeply dipping major fault, as inferred by Snook (1965, p. 764). Moreover, the pattern of thrust faults and overturned folds in the adjacent Cave Mountain Formation, and the general east-west orientation of compressional forces indicated by this pattern, further suggest that this deformation resulted from forcible emplacement of the gneiss dome.

In the Loomis quadrangle to the north, the Anarchist Group and Kobau Formation were strongly folded on northwest to northnorthwest axes, then refolded in places on east to northeast axes (Rinehart and Fox, 1972, p. 68, 72). The earlier folding was dated as Triassic. Refolding during the second episode was provisionally regarded as Jurassic or Cretaceous because of its parallelism with folds attributed by Yates and others (1966) to this period in northeastern Washington, and we know of no local evidence on which to date folds of this episode more precisely.

Work in progress indicates that the radiometric age of the Okanogan gneiss dome is Late Cretaceous. If this is also the age of its emplacement, as seems likely, then the age of the third episode of folding is also Late Cretaceous.

\section{DEFORMATIONAL HISTORY}

The complex configuration of major folds in the Conconully quad- 
rangle appears to be a product of three or more episodes of folding, the first two of regional extent, the last local, having affected rocks along the eastern side of the quadrangle only. The major structural grain in the Permian and Triassic rocks is north to northwest, but that grain is interrupted by an east-trending structural belt, partly defined by the contact of the metamorphic complex of Conconully with the Anarchist Group and also by northeast-trending minor folds in the Schallow Mountain area. It is further interrupted by the broad, east-northeast-trending anticline in the Cave Mountain Formation in the south-central part of the quadrangle. This anticline is apparently truncated on the east by a set of north- to northwest-trending overturned folds and associated thrust or reverse faults whose origin is attributed to forcible emplacement of the adjacent gneiss dome.

The sequence of the three episodes of folding, therefore, was: (1) pervasive regional folding on northwest- to north-trending axes; (2) localized crossfolding of earlier structures, probably on northeast- to east-trending axes, and (3) crossfolding of earlier structures in the area marginal to the western contact of the Okanogan gneiss dome, with fold trends generally parallel to this contact, in places coincident, or nearly so, with folds of the first episode. Folds of the first episode in the Anarchist Group of the north-central part of the quadrangle are cut by the Loomis pluton and hence must be Late Triassic or older. Folds of the second and third episodes involve rocks of Late Triassic age and must be Late Triassic or younger.

The deformational and intrusive history indicated by interrelations of structural features in the Conconully quadrangle is in inferred chronological sequence:

(1) Regional folding of the Permian and Triassic sequence before the end of the Triassic. Major folds and minor folds and crenulations, and axial-plane cleavage formed in the west-central and northern sectors. The carbonate sequence in the south was broadly domed.

(2) Onset of plutonism in Late Triassic and a concurrent episode of metamorphism. This episode was a long one that began in the stress environment of the preceding phase. Wallrocks were deformed, in part plastically, to accommodate large, concordant, generally elongate plutons. The structural dome in the Funk Mountain-Schallow Mountain area probably formed at this time. The Loomis pluton and the porphyroblastic granitoid gneiss and metadiorite and metaquartz diorite units were probably emplaced during this episode.

(3) Deformation, contact metamorphism, and plutonism, probably in the Jurassic and(or) Cretaceous. During this episode, the rocks were locally refolded on east- to northeast-trending axes. Earlier plutons, especially smaller ones such as the metadiorite and meta-quartz diorite, were deformed, as were the previously metamorphosed rocks, 
but within a stress field somewhat differently oriented from that of previous phases. This deformation is shown by refolding of minor folds at several localities but is especially evident in the Funk Mountain-Schallow Mountain area. The Blue Goat pluton may have been emplaced before the end of this episode for although it cuts metamorphic rocks discordantly, rocks of the pluton locally are foliated and show some evidence of cataclasis, indicating postconsolidation dynamic metamorphism. The Evans Lake pluton shows similar evidence of structural deformation and may have been dynamically metamorphosed concurrently with the Blue Goat pluton, but both plutons may well have undergone dynamic metamorphism during a much later episode. Thrusting along the Cayuse Mountain fault probably followed the crossfolding of this episode, and certainly preceded vulcanism and sedimentation in the Eocene.

(4) Intense deformation on the east and passive plutonic emplacement on the west, during the Cretaceous and including the earliest Tertiary. This period includes the intrusion of the quartz monzonite pluton of Salmon Creek, which now occupies more than $130 \mathrm{~km}^{2}(50$ $\mathrm{mi}^{2}$ ) west and south of the Conconully quadrangle and is virtually devoid of metamorphic and deformational structures. By contrast, rocks in the southeastern quadrant underwent fairly intense deformation, without appreciable contact metamorphism, caused by and localized adjacent to the intrusive Okanogan gneiss dome. Overturned folds, thrust faults, and otherwise chaotic distortion of the earlier domal structure and superimposed east-northeast-trending anticline in the Cave Mountain Formation west of Wagonroad Coulee probably resulted from emplacement of the salient of gneiss that extends into the quadrangle from the east.

(5) The final event was mainly normal faulting along approximately north-striking faults with displacements of perhaps hundreds of metres. Although faulting occurred after eruption of the Eocene volcanic rocks, it probably began much earlier, judging from the substantially greater offsets in metamorphic bedrock. Some postvolcanic eastward tilting is suggested by attitudes in the volcanic terrane.

\section{MINERAL DEPOSITS}

Metallic mineral deposits, chiefly silver and lead but including some copper and gold, are mostly clustered in the southwestern corner of the quadrangle and, together with other deposits adjacent on the west and south, constitute the Conconully-Ruby mining district. Mining activity reached its peak before the turn of the century, and many mine workings were already caved or otherwise inaccessible by 1915 when they were visited briefly and subsequently described (1916) by E. L. Jones, Jr. The history and general geology of 
these and other deposits within the quadrangle have been recently described by Moen (1973.)

The deposits are quartz-filled fissure veins that are typically concordant with structures in the host rock. The most common ore mineral is galena, generally accompanied by pyrite and, locally, by varied but lesser amounts of sphalerite and chalcopyrite. The veins characteristically contain ore minerals in shoots that are sporadically distributed and that pinch and swell abruptly. The sporadic and discontinuous nature of the deposits, along with declining silver prices and the lack of a nearby railroad, led to the demise of the district probably before production values greatly exceeded a quarter of a million dollars. Activity from 1916 to date has been minor, and it is doubtful that total production ever reached half a million dollars.

In addition to the fissure-vein deposits typical of the ConconullyRuby district, two disseminated-type deposits occur in the northern part of the quadrangle: the Q. S. copper deposit, and the Starr molybdenum deposit. The Q. S. copper deposit is exposed below the rim of the steep eastern escarpment of the Sinlahekin Valley opposite Blue Lake, where normally dark metasiltstone and greenstone country rocks are bleached and stained with limonite over several thousand square metres. Several bright-green patches of malachite can be seen from a distance in the nearly vertical face of the cliff. Exposures at the base of the cliff and rock dumps at the portals of two adits, at altitudes of 2,000 and 3,000 feet, are mainly schistose, pyritic greenstone. The presence of chalcopyrite with pyrite was reported by Jones (1916). Little work appears to have been done since Jones' visit, and no production is recorded.

The Starr molybdenum deposit is in the Aeneas Creek pluton in the northeastern part of the quadrangle. Chief ore minerals are molybdenite, chalcopyrite, pyrite, arsenopyrite, and scheelite and molybdite. The deposit was described by Creasey (1954), who observed that ore minerals coat fractures and fill interstices in breccia zones that probably formed at intersections of two sets of faults. $\mathrm{He}$ concluded that the property contained approximately 800,000 tons of indicated ore averaging 0.30 percent $\mathrm{MoS}_{2}$. The only recorded production was 3,000 tons of ore in 1939 .

In addition to the more comprehensive information given by Moen (1973), most deposits in the quadrangle that were exploited or extensively explored are included in compendiums by Huntting (1956) and Valentine (1960). Results of a geochemical exploration program that included the Conconully as one of four 15-minute quadrangles covered by the survey are presented in a report recently published (Fox and Rinehart, 1972).

Nonmetallic mineral deposits, in addition to probable large but 
undeveloped deposits of sand and gravel within glacial drift and alluvium, include limestone (Mills, 1962) and dolomite (Bennett, 1944) of potentially commercial value in the carbonate sequence between Conconully and Riverside. Several unexplored deposits of magnesitic dolomite (see description of metadolomite and metalimestone member of the Cave Mountain Formation) and of fluorite also are present.

Mills (1962, p. 230) mapped and sampled limestone, here correlated with the Cave Mountain Formation, in the Dunn Mountain area and the Frye Lake area. His samples were small chips taken from the surface of outcrops at $3-\mathrm{m}$ (10-ft) intervals across the strike of the strata, then combined into one sample of about $4 \mathrm{~kg}(9 \mathrm{lb})$ weight for each $15 \mathrm{~m}(50 \mathrm{ft})$ or so of traverse.

Limestone at the Frye Lake area (sec. 26, T. 35 N., R. 26 E.) was described as gray, fine grained, siliceous, and argillaceous. This rock forms the basal part of the slate and metalimestone member of the Cave Mountain Formation in this area. The average compsition, on the basis of analysis of five samples representing a true thickness of about $92 \mathrm{~m}$ ( $300 \mathrm{ft}$ ), is 62.80 percent $\mathrm{CaCO}_{3}, 1.96$ percent $\mathrm{MgO}, 27.87$ percent $\mathrm{SiO}_{2}, 5.26$ percent $\mathrm{R}_{2} \mathrm{O}_{3}$, and 0.084 percent $\mathrm{P}_{2} \mathrm{O}_{5}$. The limestone is thus much too impure to be of value for most industrial uses.

In the Dunn Mountain area, limestone from both the basal darkgray metalimestone member and the younger metadolomite and metalimestone member were investigated by Mills (1962, p. 232 236). Outcrops of the dark-gray metalimestone member at localities in section 12 (T. 35 N., R. 25 E.) and section 7 (T. 35 N., R. 26 E.) were described as dark-gray, fine- to medium-grained siliceous limestone. The composition of this rock, on the basis of eight samples representing an aggregate thickness of about $96 \mathrm{~m}$ (314 ft), averaged 77.54 percent $\mathrm{CaCO}_{3}, 1.37$ percent $\mathrm{MgO}, 17.27$ percent $\mathrm{SiO}_{2}, 1.76$ percent $\mathrm{R}_{2} \mathrm{O}_{3}$, and 0.108 percent $\mathrm{P}_{2} \mathrm{O}_{5}$; this rock also is much too impure to be of value for most uses.

Limestone of the metadolomite and metalimestone member at four localities southeast of Dunn Mountain was described as white to light-gray, medium-grained limestone and white, coarse-grained limestone. Mill's average compositions for the four localities, on the basis of 16 samples representing a total sample length of over $185 \mathrm{~m}$ $(600 \mathrm{ft})$, are as follows (1962, p. 234-235):

\begin{tabular}{|c|c|c|c|c|c|}
\hline Locality & $\mathrm{CaCO}_{3}$ & MgO & $\mathrm{SiO}_{2}$ & $\mathrm{R}_{2} \mathrm{O}_{3}$ & $\mathrm{P}_{2} \mathrm{O}_{5}$ \\
\hline $\mathrm{SE}^{1 / 4}$ sec. 1 , T. 35 N., R. 25 E. & -...- 89.00 & 0.91 & 7.56 & 1.15 & 0.099 \\
\hline SW1/4SW1/4 sec. 6 , T. 35 N., R. 26 E. & 89.98 & 1.22 & 5.10 & 1.43 & \\
\hline $\begin{array}{l}\mathrm{SE}^{1 / 4 \mathrm{NE}^{1} / 4} \text { sec. } 12, \text { T. } 35 \text { N., R. } 25 \text { E. } \\
\text { and NW1/4SW1/4 sec. } 7 \text {, T. } 35 \text { N., R. } 26 \text { E. }\end{array}$ & & .96 & 3.32 & .83 & 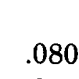 \\
\hline $\mathrm{SW}^{1 / 4} \mathrm{NE}^{1 / 4}$ sec. 12 , T. 35 N., R. $25 \mathrm{E}$. & 92.65 & 1.13 & 3.97 & .68 & \\
\hline
\end{tabular}


These analyses indicate that although this limestone is too low in lime to be rated a high-calcium limestone, it is quite suitable for the manufacture of portland cement.

This limestone, which we have described as white marble (see previous description), forms the basal part of the metadolomite and metalimestone member of the Cave Mountain Formation over much of the area between Dunn Mountain and Cave Mountain. The white marble is particularly conspicuous within the south-dipping, homoclinal sequence at Cave Mountain, south of the area investigated by Mills.

At Cave Mountain, the white marble appears to be about $170 \mathrm{~m}$ thick where intersected by cross-section $A-A^{\prime}$. If, as seems likely, much of the rock here and on strike to the west is equivalent in grade to that sampled by Mills, the unit could represent a deposit of cement-, agricultural-, or possibly chemical-grade limestone of considerable size.

The slate and metalimestone member contains near its base a white to light-gray marble that may also be of commercial quality in places (see previous description). Spotchecks of limestone hand specimens of this unit suggest that it is locally relatively pure but that it contains interlayers of dolomitic limestone, whose presence might adversely affect the grade of the deposit.

The dolomite investigated by Bennett (1944) forms much of the lower part of the metadolomite and metalimestone member of the Cave Mountain Formation in the eastern part of its outcrop area. Eight nearly continuous deposits were mapped by Bennett within the $61 / 2-\mathrm{km}$-long ( $4 \mathrm{mi}$ ) outcrop belt of the member flanking Wagonroad Coulee, between Booher Lake on the northwest and Riverside on the southeast. Two small deposits southeast of the Conconully quadrangle, but in the same outcrop belt, were also investigated. Bennett concluded (1944, p. 25) that the 10 deposits totaled about $290,000,000$ short tons of dolomite, while noting that the estimated tonnage is not all high-purity dolomite. Inspection of the analyses suggests that while high-purity dolomite is indeed present, quite possibly in minable bodies, much is of marginal or inferior quality because of high silica content.

Fluorite was found at two localities within the Conconully quadrangle, one in $\mathrm{N}^{1} 1 / 2$ sec. 32 , T. $36 \mathrm{~N}$., R. 26 E., the other in sec. 12 , T. $36 \mathrm{~N}$., R. $26 \mathrm{E}$. At the former, colorless fluorite crystals as large as $1 \mathrm{~cm}$ (0.4 in.) across are distributed through a quartz-carbonate breccia along an unmapped reverse fault at the northern base of an outcrop of massive vein(?) quartz. Surfaces of the massive quartz outcrop, especially those exposed by recent spalling, commonly show slickensides trending in diverse directions. The massive quartz is laced by myriad 
ramifying quartz veinlets and is variably brecciated, although the breccia is everywhere highly lithified. A thin section of the breccia shows fragments of mosaic quartz in a matrix of fine-grained quartz through which coarser grains or patches of fluorite are scattered.

In sec. 12, purple fluorite is found in the small outcrop of granitic rock near the quadrangle boundary where it occurs in a boxwork of veinlets that penetrates a body of crushed, albitized, and bleached granodiorite, which superficially resembles alaskite. Traces of fluorite are also present $900 \mathrm{~m}(3,000 \mathrm{ft})$ to the northwest, in NE1/4 sec. 12, in the Tonasket quadrangle. There, the fluorite is patchily distributed within a 0.9 - to $3-\mathrm{m}$-thick ( 3 to $10 \mathrm{ft}$ ) layer of weakly metamorphosed dolomitic limestone of the Anarchist Group. The fluorite appears to be localized along the crestal part of a small anticline.

\section{REFERENCES CITED}

Adams, R. W., 1962, Geology of the Cayuse Mountain-Horse Springs Coulee area, Okanogan County, Washington: Washington Univ., Seattle, M.S. thesis.

Bennett, W. A. G., 1944, Dolomite resources of Washington: Part 1: Washington Div. Mines and Geology Rept. Inv. 13, 35 p.

Creasey, S. C., 1954, Geology of the Starr molybdenum mine, Okanogan County, Washington, in Purdy, C. P., Jr., Molybdenum occurrences of Washington: Washington Div. Mines and Geology Rept. Inv. 18, p. 51-62.

Daly, R. A., 1912, Geology of the North America Cordillera at the forty-ninth parallel: Canada Geol. Survey Mem. 38, pts. 1-3, 857 p.

Fox, K. F., Jr., and Rinehart, C. D., 1968, Geology of magnesite deposits in northern Okanogan County, Washington-A preliminary report: U.S. Geol. Survey Bull. 1272-B, $15 \mathrm{p}$.

1971, Okanogan Gneiss Dome, north-central Washington (abs.): Symposium on Metamorphism in the Canadian Cordillera, Cordilleran Sec., Geol. Assoc. Canada, Vancouver, B.C., p. 10.

1972, Distribution of copper and other metals in gully sediments of part of northern Okanogan County, Washington: Washington Div. Mines and Geology Bull. 65, $38 \mathrm{p}$.

Fox. K. F., Jr., Rinehart, C. D., and Engels, J. C., 1973, Mesozoic plutonic history of Okanogan County, north-central Washington: Geol. Soc. America Abs. with Programs, v. 5 , no. 1, p. 44.

Fox, K. F., Jr., Rinehart, C. D., Engels, J. C., and Stern, T. W., 1976, Age of emplacement of the Okanogan gneiss dome, north-central Washington: Geol. Soc. America Bull. (in press).

Goldsmith, Richard, 1952, Petrology of the Tiffany-Conconully area, Okanogan County, Washington: Washington Univ., Seattle, Ph.D. thesis, 356 p.

Grose, L. T., 1949, A petrogenetic study of the Evans Lake granodiorite, Omak, Washington: Washington Univ., Seattle, M.S. thesis, 90 p.

Hibbard, M. J., 1971, Evolution of a plutonic complex, Okanogan Range, Washington: Geol. Soc. America Bull., v. 82, p. 3013-3048.

Huber, N. K., and Rinehart, C. D., 1966, Some relationships between the refractive index of fused glass beads and the petrologic affinity of volcanic rock suites: Geol. Soc. America Bull., v. 77, p. 101-110.

Huntting, M. T., 1956, Metallic minerals, Part 2 of Inventory of Washington minerals: Washington Div. Mines and Geology Bull. 37, v. 1, 428 p. 


\section{8}

Jones, E. L., Jr., 1916, Reconnaissance of the Conconully and Ruby mining districts, Washington: U.S. Geol. Survey Bull. 640-B, p. 11-36.

Menzer, F. J., Jr., 1965, Geology of the crystalline rocks west of Okanogan, Washington: Dissert. Abs., v. 25, no. 12, pt. 1.

1970, Geochronologic study of granitic rocks from the Okanogan Range, northcentral Washington: Geol. Soc. America Bull., v. 81, p. 573-578.

Mills, J. W., 1962, High-calcium limestones of eastern Washington: Washington Div. Mines and Geology Bull. 48, 268 p.

Misch, Peter, 1949a, Metasomatic granitization of batholithic dimensions; Part III, Relationships of synkinematic and static granitization: Am. Jour. Sci., v. 247, p. 673-705.

$-1949 \mathrm{~b}$, Structure, metamorphism, and granitization in part of Okanogan County, north-central Washington (abs.): Geol. Soc. America Bull., v. 60, no. 12, p. 1942.

1951, Large thrusts in northern Cascades of Washington (abs.): Geol. Soc. America Bull., v. 62, no. 12, pt. 2, p. 1508-1509.

1966, Tectonic evolution of the northern Cascades of Washington State: Canadian Inst. Mining and Metallurgy Spec. Vol. 8, p. 101-148.

Moen, W. S., 1973, Conconully mining district, Okanogan County, Washington: Washington Div. Mines and Geology Inf. Circ. 49, $42 \mathrm{p}$.

Nockolds, S. R., 1954, Average chemical compositions of some igneous rocks: Geol. Soc. America Bull., v. 65, no. 10, p. 1007-1032.

Norman, M. B., II, 1974, Improved techniques for selective staining of feldspar and other minerals using amaranth: U.S. Geol. Survey Jour. Research, v. 2, no. 1, p. 73-79.

Peacock, M. A., 1931, Classification of igneous rocks series: Jour. Geology, v. 39, no. 1, p. 54-67.

Pelton, H. A., 1957, Geology of the Loomis-Blue Lake area, Okanogan County, Washington: Washington Univ., Seattle, M.S. thesis, 92 p.

Rice, H. M. A., 1960, Geology and mineral deposits of the Princeton map area, British Columbia: Canada Geol. Survey Mem. 243, 136 p.

Rinehart, C. D., and Fox, K. F., Jr., 1972, Geology and mineral deposits of the Loomis quadrangle, Okanogan County, Washington: Washington Div. Mines and Geology Bull. 64, $124 \mathrm{p}$.

Rittman, Alfred, 1952, Nomenclature of volcanic rocks: Bull. Volcanology, ser. 2, v. 12, p. 75-102.

Shapiro, Leonard, and Brannock, W. W., 1956, Rapid analysis of silicate rocks: U.S. Geol. Survey Bull. 1036-C, p. 19-56.

Snook, J. R., 1965, Metamorphic and structural history of "Colville batholith" gneisses, north-central Washington: Geol. Soc. America Bull., v. 76, no. 7, p. 759-776.

U.S. Geological Survey, 1970, Geological Survey research, chapter A: U.S. Geol. Survey Prof. Paper 700-A, 425 p.

Valentine, G. M., 1960, Inventory of Washington minerals-Part 1, Nonmetallic minerals: Washington Div. Mines and Geology Bull. 37, v. 1 (text), 175 p., v. 2 (maps), 83 p., revised by M. T. Huntting, 1960; orig. pub. 1949.

Waters, A. C., and Krauskopf, K. B., 1941, Protoclastic border of the Colville batholith (Washington): Geol. Soc. America Bull., v. 52, no. 9, p. 1355-1417.

Yates, R. G., Becraft, G. E., Campbell, A. B., Pearson, R. C., 1966, Tectonic framework of northeastern Washington, northern Idaho, and northwestern Montana, in A symposium on the tectonic history and mineral deposits of the western Cordillera, Vancouver, B.C., 1964: Canadian Inst. Mining and Metallurgy Spec. Vol. 8, p. $47-59$. 
. 
. 